\title{
EFFECTS OF ORGANIC NUTRIENT AMENDMENTS ON WEED AND CROP GROWTH
}

\author{
A Thesis \\ Presented to the Faculty of the Graduate School \\ of Cornell University \\ In Partial Fulfillment of the Requirements for the Degree of \\ Master of Science
}

by

Neith Grace Little

August 2013 
(C) 2013 Neith Grace Little 


\begin{abstract}
Sufficient fertility is important for crop yield but supplying a balanced amount of each nutrient with compost is challenging and nutrient imbalances can benefit weeds more than crops. This work's goal was to partition out effects of nitrogen $(\mathrm{N})$, phosphorus (P), and potassium $(\mathrm{K})$ from composted poultry manure on growth of corn, lettuce, kale, and common weeds Powell amaranth, common lambsquarters, giant foxtail, and velvetleaf. Plants were grown in the field in soil amended with compost or organic single-nutrient $\mathrm{N}, \mathrm{P}$, and $\mathrm{K}$ amendments. $\mathrm{P}$ amendment as bone char did not mimic $\mathrm{P}$ supply from compost. Weeds responded more strongly than corn to compost. Velvetleaf response to compost appeared driven by N. Responses of other weeds and lettuce to compost were not due to $\mathrm{N}$ or $\mathrm{K}$, and may have been driven by $\mathrm{P}$ or another nutrient. These results support fertility management based on soil testing and anticipated crop needs.
\end{abstract}




\section{BIOGRAPHICAL SKETCH}

Neith Grace Little was born July 6, 1987 to Maryalice Kaprielyan Little and Brian Little, who supported her interest in plants, ecology, and agriculture throughout a rural childhood spent mostly in Painted Post, NY. Participation in the Girl Scouts of America was an early formative experience which included many camping trips and a junior zookeeper program at Busch Gardens Tampa, made possible by a local branch of the Audubon Society. In 2005, Neith was awarded the Girl Scout Gold Award for developing and presenting a series of workshops on composting and recycling to younger scouts. Neith also enjoyed working at the Spencer Crest Nature Center and at Massi's Gardens and Landscaping, volunteering at the Big Flats Plant Materials Center, and reading everything she could get her hands on.

In 2005, Neith began attending College of the Atlantic (COA, where she made life-long friends and was inspired by many wonderful professors, including her academic adviser, Dr. Suzanne Morse. While at COA, Neith worked as a peer writing tutor, as a statistics teaching assistant, and at the Dorr Natural History Museum. She also spent two summers in National Science Foundation Research Experiences for Undergraduates (REU) programs. The first was hosted by Dr. Gene Likens of the Cary Institute of Ecosystem Studies and was spent studying salamanders in the White Mountains of New Hampshire. The second REU was directed by Dr. Nina Theis at the University of Massachusetts Amherst and was spent investigating the pollination ecology of squash. During the latter summer, in between 4 AM squash bee surveys, Neith met Andrew Davis, who to this day continues to make early mornings (and everything else in her life) much more fun. In 2009 Neith was awarded a 
NASA/Montana Space Grant Consortium Scholarship to fund her Senior Project research on mapping and predicting the spread of the invasive vines white swallowwort and black swallowwort. In June 2009, Neith received the Bachelor of Arts in Human Ecology from College of the Atlantic.

In the fall of 2009, Neith began attending graduate school at Cornell University, field of Soil and Crop Sciences, with support from a Cornell Graduate School Fellowship. She was advised by Dr. Antonio DiTommaso, Dr. Charles Mohler, and Dr. Quirine Ketterings. In the 2011-2012 academic year, Neith worked as a Teaching Assistant for the course Investigative Biology. Throughout her time at Cornell, she participated in student governance through the Graduate and Professional Student Association (GPSA). In 2011, Neith was awarded the MacDonald/Musgrave Graduate Student Award for Excellence by the Department of Crop and Soil Science. Neith currently works at Hampshire College in Amherst, Massachusetts, both on the college's student farm and in the sustainability office. She particularly enjoys operating tractors. 
To my Mom and Dad, my sister Hannah, my grandparents, Andrew, and all the other kind, beloved people who gave me a chance, inspired me, and made me smile 


\section{ACKNOWLEDGMENTS}

This thesis would never have been completed without the help of a great many people. I don't have enough room to give you all the thanks you deserve. Thank you all so much.

My graduate advising committee never gave up, even when some experiments did not work, and gave generously of their time. The idea for this research project and the conceptual framework in the review paper were developed by Dr. Charles Mohler. He spent an incredible amount of time talking with me about experimental design and statistics, helping with field operations, reading and editing paper drafts, and even directing a student carpentry crew in his driveway when we needed to build several hundred wooden boxes. Dr. Antonio DiTommaso led the lab that was my professional home at Cornell and encouraged me to present at conferences and compete in the Weed Science Olympics. He also reviewed experiment plans and draft after draft of this thesis, and read the mountain of papers cited in the review paper. Dr. Quirine Ketterings brought soil fertility expertise to this project, advising on experimental design and interpretation (even via Skype when necessary), sharing laboratory equipment, and giving me the opportunity to present this work to extension educators. The incubation study was her idea and was mostly conducted in her lab.

I would never have gotten to graduate school, and certainly would not have gotten through it without the support of family, friends, and innumerable kind people who helped me along the way. In particular, I want to thank my parents for teaching me to love learning, Hannah for being my sister no matter what, Andrew for bringing me joy, Amanda and Carri for giving me shoulders to cry on, my professors at COA 
for their infectious enthusiasm, and Nancy Hanson and Dr. Beth Hooker for giving me hope for life after graduate school.

The staff of the DiTommaso Lab, Cornell Nutrient Management Spear Lab, Drinkwater Lab, and Cornell Nutrient Analysis Lab helped with field experiments, patiently taught me to use various types of laboratory equipment, and encouraged me to keep trying when things got difficult. Thank you so much to Caroline Marschner, Brian Caldwell, Scott Morris, Katherine Howard, Dr. Sanjay Gami, Gregory Godwin, Shona Ort, Eun mee Hong, Elizabeth Buck, Sean Berthron, Heather Scott, Alejandro Parra, Tatyana Dokuchayeva, Elizabeth Woodring, and Dawn Moser. I could fill an entire volume the size of this thesis with stories of times you saved the day.

Field operations were carried out by a small army of unstoppable student research assistants: Brett Morgan, Carly Neumann, Daniel Demeree, Jingru Huan, Ariel Saffer, Bonnie Cherner, Carrie Carlton, Thomas Paul, Brian Karlowitz, Ross Hathaway, Ava Ryan, Sara Orlowski, and Cristina Dykeman. Thank you for digging all those holes, thinning all those foxtail seedlings, grinding all those plant samples, and putting up with my early attempts at leadership.

This work was supported by a grant from the USDA Organic Research and Extension Initiative (number 2009-51300-05586), two grants from the Toward Sustainability Foundation, and by the Cornell University Agricultural Experiment Station federal formula funds, Project Numbers NYC-145843 (MultiState Hatch Project NE-1026) and NYC-125800 (MultiState Hatch Project NE-1047) received from the National Institute of Food and Agriculture (NIFA), United States Department of Agriculture. 


\section{TABLE OF CONTENTS}

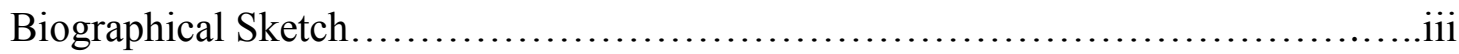

Acknowledgements........................................................

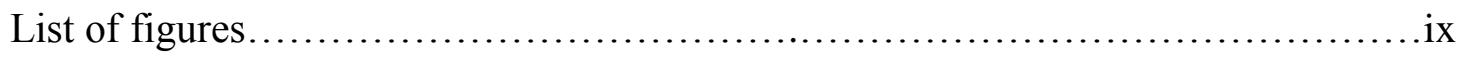

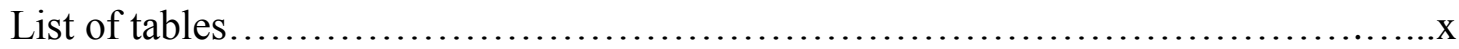

Chapter 1: Effects of fertility management on weed growth and crop-weed

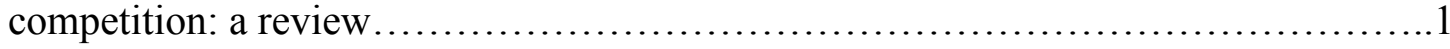

Chapter 2: Effects of organic nutrient amendments on weed and crop growth........44 


\section{LIST OF FIGURES}

CHAPTER 1:

No figures

CHAPTER 2:

Figure 2.1 Illustration of open-bottomed wooden boxes in which plants were grown during the 2010 field experiment..........................52

Figure 2.2 Illustration of layout of the 2011 field experiment..................58

Figure 2.3 Examples of two Equation 1 models fitted to points generated with the Mitscherlich equation.......................................63

Figure 2.4 Nitrogen release and nitrification over time in soil amended with compost, blood meal, or urea................................64

Figure 2.5 Weed growth across increasing amendment with composted poultry

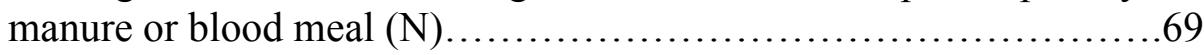

Figure 2.6 Crop growth across increasing amendment with composted poultry

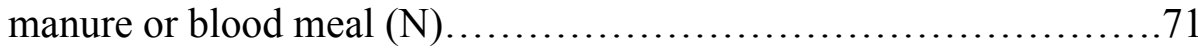




\section{LIST OF TABLES}

\section{CHAPTER 1:}

Table 1.1 Summary of published research on weed species responsiveness to the

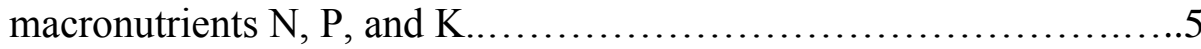

Table 1.2 Scenario 1 of the conceptual framework - crop and weed competition is unaffected by the added nutrient $\ldots \ldots \ldots \ldots \ldots \ldots \ldots \ldots \ldots \ldots \ldots \ldots \ldots \ldots$

Table 1.3 Scenario 2-no strong asymmetric competition for light...............13

Table 1.4 Scenario 3-symmetric competition for light before canopy closure, asymmetric competition afterwards.............................14

Table 1.5 Scenario 4-strong asymmetric competition for light by the time of canopy closure.............................................16

\section{CHAPTER 2:}

Table 2.1 Macronutrients applied in each fertility treatment and amendment rate..........................................................51

Table 2.2 Planting dates and days after planting (DAP) of field operations for the field experiments. ...........................................53

Table $2.3 \quad$ Treatments in 2011 field experiment. ............................56

Table 2.4 Mean $\mathrm{pH}$, organic matter, and Morgan extractable $\mathrm{P}$ and $\mathrm{K}$ results for soil samples from the 2010 and 2011 field experiments.............67

Table 2.5 Significance of analysis of variance for aboveground biomass of the crops and weeds which exhibited linear responses to increasing fertility rate.

Table 2.6 F-test comparison of the difference between the residual sum of squares of Equations 1 and 2 as models for aboveground biomass..............70 


\title{
CHAPTER 1
}

\section{EFFECTS OF FERTILITY MANAGEMENT ON WEED GROWTH AND CROP-WEED COMPETITION: A REVIEW}

\author{
Neith G. Little, Antonio DiTommaso, Quirine M. Ketterings, and Charles L. Mohler* \\ * First, second, and fourth authors: Graduate Student, Associate Professor, and Senior Research \\ Associate Department of Crop and Soil Sciences, Cornell University, Ithaca, NY 14853. Third \\ author: Associate Professor, Department of Animal Science, Cornell University, Ithaca, NY \\ 14853. Corresponding author's E-mail: ng17@cornell.edu
}

\begin{abstract}
Illuminating the ways in which fertility management and weed management are interrelated is an important step in developing practical methods for integrated weed management. Studies on the effect of soil fertility levels and nutrient addition on the growth of weeds in monoculture enable researchers to determine the inherent responsiveness of a species to nutrients under controlled conditions. Such studies have shown that nitrogen $(\mathrm{N})$ fertilizers can stimulate germination and emergence of some weeds. Equally important, the growth of many common weeds is highly responsive to soil amendment with $\mathrm{N}$, phosphorus (P), and potassium (K). Nevertheless, studies have reported varying effects of fertility on competition between weeds and crops. A conceptual framework, based on variation in crop and weed competitiveness and responsiveness to fertility, is proposed. The goal of this framework is to help
\end{abstract}


researchers consider the underlying mechanisms that lead to varying effects of fertility addition on yield of weedy crops. Increasing understanding of the effect of fertility on weed-crop competition has enabled development of management practices, including manipulation of fertility placement, timing of availability, and source of nutrients, which can help optimize nutrient supply to crops while minimizing nutrient supply to weeds. Future research topics on the integration of fertility and weed management are recommended. These explore underlying mechanism that may explain varying effects of fertility addition on weed-crop competition. The advancing fields of root imaging and soil ecology integrated with mechanistic studies of how fertility affects crop-weed competition can potentially make a substantial contribution to integrated weed management.

\section{Key words}

Fertility management, fertilizers, compost, manure, green manure, nitrogen, phosphorus, potassium, sulfur, macronutrients, banding, timing of nutrient supply 


\section{Introduction}

Illuminating the ways in which fertility management and weed management are interrelated is an important step in developing practical methods for integrated weed management (Buhler 2002). This topic was last reviewed by Di Tomaso (1995). At that time, most research focused on the effects of nitrogen $(\mathrm{N})$ fertilizers. The current review covers published research on the effects of $\mathrm{N}$ (focusing on papers published since 1995), phosphorus (P), and potassium (K), supplied by either conventional or organic sources, on growth and competition of annual crops and weeds. Soil fertility affects plant competition in natural ecosystems and the competitive ability of invasive weeds (DiTommaso and Aarssen 1989) but this review will focus on agricultural systems only.

The review will consider three main questions:

1. How are common weed species affected by soil fertility?

2. Under what circumstances of crop-weed competition will addition of nutrient sources increase, decrease, or have no effect on crop yield?

3. How can fertility placement, timing, and source be manipulated to reduce the impact of weed competition on crop yield?

\section{Weed Growth in Monoculture: How are Common Weed Species Affected by Soil} Fertility?

Studies on the effect of soil fertility levels and nutrient addition on the growth of weeds in monoculture enable researchers to determine the inherent responsiveness of a species to nutrients under controlled, conditions. Species characteristics studied 
may include responsiveness of germination, emergence, growth, and reproduction to increasing fertility; tolerance to low fertility, including ability to extract nutrients from soil; nutrient use efficiency; and tissue nutrient accumulation, including luxury consumption. Nitrogen addition can stimulate germination and emergence of some weeds (Brainard et al. 2006; Sardi and Beres 1996; Sweeney et al. 2008; Williams and Harper 1965) and soaking seeds in a urea solution is a common method for stimulating weed germination (Buhler and Hoffman 1999). However, the stimulatory effect of $\mathrm{N}$ appears to depend on the presence of other dormancy inhibitors or stimulators (Gallagher and Cardina 1998; Sweeney et al. 2008). The effect of $\mathrm{N}$ on germination may also be dependent on the maternal environment of the seed (Fawcett and Slife 1978), though other studies have found no maternal effect (Brainard et al. 2006).In addition, fertility conditions in the maternal environment can affect seedling growth after germination (Wulff and Bazzaz 1992; Hrdličková et al. 2011).

Across studies, certain common weeds have been particularly responsive to N, $\mathrm{P}$ and $\mathrm{K}$ addition(Table 1.1). Although the literature on the effect of addition of other macro- and micronutrients is scant, a study by Grant et al. (2007) found that weeds in the Brassicaceae are particularly responsive to sulfur. Often the species which have the most extreme growth response to added fertility are also the species most negatively affected by low fertility (Hoveland et al. 1976; Harbur and Owen 2004; Qasem and Hill 1995; Shipley and Keddy 1988). 
Table 1.1: Weed species, listed by family, reported as highly responsive to at least two of the macronutrients N, P, or K or reported as highly responsive to one of the macronutrients in at least two separate studies (continued on next page).

\begin{tabular}{|c|c|c|c|c|c|}
\hline \multirow[t]{2}{*}{ Family } & \multirow[t]{2}{*}{ Common name } & \multirow[t]{2}{*}{ Latin name } & \multicolumn{3}{|c|}{ References for responsiveness to } \\
\hline & & & $\mathrm{N}$ & $P$ & $\mathrm{~K}$ \\
\hline Amaranthaceae & $\begin{array}{l}\text { Redroot } \\
\text { pigweed }\end{array}$ & $\begin{array}{l}\text { Amaranthus } \\
\text { retroflexus L. }\end{array}$ & $\begin{array}{l}\text { Berger et al. (2007) } \\
\text { Blackshaw et al. (2003) }\end{array}$ & Hoveland et al. (1976) & $\begin{array}{l}\text { Hoveland et al. } \\
\text { (1976) }\end{array}$ \\
\hline Asteraceae & Dandelion & $\begin{array}{l}\text { Taraxacum } \\
\text { officionale G. H. } \\
\text { Weber ex Wiggers }\end{array}$ & & Hoveland et al. (1976) & $\begin{array}{l}\text { Hoveland et al. } \\
\text { (1976) }\end{array}$ \\
\hline Asteraceae & $\begin{array}{l}\text { Scentless } \\
\text { chamomile }\end{array}$ & $\begin{array}{l}\text { Tripleurospermum } \\
\text { perforata (Mérat) } \\
\text { M. Lainz }\end{array}$ & & Blackshaw et al. (2004) & Grant et al. (2007) \\
\hline Brassicaceae & Wild mustard & Sinapis arvensis L. & $\begin{array}{l}\text { Blackshaw et al. } \\
(2003) \\
\text { Harbur and Owen (2004) }\end{array}$ & Hoveland et al. (1976) & $\begin{array}{l}\text { Hoveland et al. } \\
\text { (1976) }\end{array}$ \\
\hline Chenopodiaceae & $\begin{array}{l}\text { Common } \\
\text { lambsquarters }\end{array}$ & $\begin{array}{l}\text { Chenopodium } \\
\text { album L. }\end{array}$ & $\begin{array}{l}\text { Berger et al. (2007) } \\
\text { Blackshaw et al. (2003) } \\
\text { Harbur and Owen (2004) }\end{array}$ & & $\begin{array}{l}\text { Grant et al. (2007) } \\
\text { Hoveland et al. } \\
\text { (1976) }\end{array}$ \\
\hline Chenopodiaceae & Kochia & $\begin{array}{l}\text { Kochia scoparia } \\
\text { (L.) Schrad. }\end{array}$ & Blackshaw et al. (2003) & & Grant et al. (2007) \\
\hline Fabaceae & $\begin{array}{l}\text { Florida } \\
\text { beggarweed }\end{array}$ & $\begin{array}{l}\text { Desmodium } \\
\text { tortuosum (Sw.) } \\
\text { DC. }\end{array}$ & & Hoveland et al. (1976) & $\begin{array}{l}\text { Hoveland et al. } \\
\text { (1976) }\end{array}$ \\
\hline Geraniaceae & $\begin{array}{l}\text { Redstem } \\
\text { filaree }\end{array}$ & $\begin{array}{l}\text { Erodium cicutarium } \\
\text { (L.) L'Her. ex. Ait. }\end{array}$ & $\begin{array}{l}\text { Blackshaw et al. } \\
\text { (2003) }\end{array}$ & Blackshaw et al. (2004) & \\
\hline
\end{tabular}


Table 1.1: continued from previous page

\begin{tabular}{|c|c|c|c|c|c|}
\hline \multirow[t]{2}{*}{ Family } & \multirow[t]{2}{*}{ Common name } & \multirow[t]{2}{*}{ Latin name } & \multicolumn{3}{|c|}{ References for responsiveness to } \\
\hline & & & $\mathrm{N}$ & $\mathrm{P}$ & $\mathrm{K}$ \\
\hline Lamiaceae & $\begin{array}{l}\text { Common } \\
\text { hempnettle }\end{array}$ & $\begin{array}{l}\text { Galeopsis tetrahit } \\
\text { L. }\end{array}$ & $\begin{array}{l}\text { Blackshaw et al. } \\
\text { (2003) }\end{array}$ & Blackshaw et al. (2004) & \\
\hline Lamiaceae & Henbit & $\begin{array}{l}\text { Lamium } \\
\text { amplexicaule L. }\end{array}$ & & Blackshaw et al. (2004) & $\begin{array}{l}\text { Grant et al. } \\
(2007)\end{array}$ \\
\hline Malvaceae & $\begin{array}{l}\text { Common } \\
\text { mallow }\end{array}$ & $\begin{array}{l}\text { Malva neglecta } \\
\text { Wallr. }\end{array}$ & $\begin{array}{l}\text { Blackshaw et al. } \\
(2003)\end{array}$ & Blackshaw et al. (2004) & \\
\hline Malvaceae & Velvetleaf & $\begin{array}{l}\text { Abutilon } \\
\text { theophrasti Medik. }\end{array}$ & $\begin{array}{l}\text { Berger et al. (2007) } \\
\text { Harbur and Owen (2004) }\end{array}$ & & \\
\hline Poaceae & Downy brome & Bromus tectorum L. & $\begin{array}{l}\text { Blackshaw et al. } \\
\text { (2003) }\end{array}$ & Blackshaw et al. (2004) & \\
\hline Rubiaceae & $\begin{array}{l}\text { Catchweed } \\
\text { bedstraw }\end{array}$ & Galium aparine $\mathrm{L}$. & $\begin{array}{l}\text { Blackshaw et al. } \\
\text { (2003) }\end{array}$ & Blackshaw et al. (2004) & \\
\hline Solanaceae & Jimsonweed & $\begin{array}{l}\text { Datura stramonium } \\
\text { L. }\end{array}$ & & Hoveland et al. (1976) & $\begin{array}{l}\text { Hoveland et al. } \\
\text { (1976) }\end{array}$ \\
\hline
\end{tabular}


Information about the response of a specific weed to fertility in monoculture can be used to draw conclusions about the nutrient response of general types of plants (small seeded vs. large seeded, $\mathrm{C}_{3}$ vs. $\mathrm{C}_{4}$ photosynthetic pathways, maximum relative growth rate, etc.). For example, plants which employ the $\mathrm{C}_{4}$ photosynthetic pathway require less of the Rubisco enzyme to photosynthesize. Because this enzyme is a Nrich protein, $\mathrm{C}_{4}$ plants use soil $\mathrm{N}$ and added $\mathrm{N}$ more efficiently than $\mathrm{C}_{3}$ plants; $\mathrm{C}_{4}$ plants fix more carbon and thus produce more biomass per unit $\mathrm{N}$ taken up (Ehleringer and Monson 1993). This has led some researchers to hypothesize that $\mathrm{C}_{4}$ plants should be less limited by $\mathrm{N}$ and less responsive to increasing $\mathrm{N}$ application rates than $\mathrm{C}_{3}$ plants (Harbur and Owen 2004). Alternatively, $\mathrm{C}_{4}$ species also tend to have a high maximum relative growth rate (RGR), which may enable them to take advantage of high fertility (Chapin 1980). One study found no significant difference in N sensitivity between $\mathrm{C}_{3}$ and $\mathrm{C}_{4}$ species, but this may have been an artifact of the relatively low light levels achievable in the growth chambers used (Harbur and Owen 2004). However, the same study did find that, among the eight species studied, high RGR at high $\mathrm{N}$ rate was significantly correlated with low RGR at low $\mathrm{N}$ rate, supporting the hypothesis that a trade-off exists between the ability to take advantage of high fertility and the ability to thrive under low fertility stress.

Monoculture nutrient response studies can also be used to develop hypotheses about the effect of nutrients on competition between species. For example, the results of the broad surveys of weed response to $\mathrm{N}$ and $\mathrm{P}$ conducted by Blackshaw et al. (2003, 2004) were used to guide selection of representative species with varying responses to grow in replacement series experiments testing the effect of $\mathrm{N}$ and $\mathrm{P}$ on 
competition (Blackshaw and Brandt 2008, 2009). As hypothesized, the competitive abilities of species with minimal response to $\mathrm{N}$ and $\mathrm{P}$ in monoculture (Persian darnel, Lolium persicum Boiss. \& Hohen. Ex. Boiss; Russian thistle, Salsola tragus L.) were also unaffected by nutrient rate in the replacement series experiments (Blackshaw and Brandt 2008, 2009). In the P study, competitive ability of the Persian darnell and Russian thistle was decreased by increasing P rates (Blackshaw and Brandt 2009). Also as predicted, most of the species that were highly responsive to $\mathrm{N}$ (redroot pigweed, Amaranthus retroflexus L.) or P (common mallow, Malva neglecta Wallr.) when grown in monoculture became more competitive against wheat with increasing nutrient rate. However, wild oat (Avena fatua $\mathrm{L}$.) was an exception to this trend; in the monoculture studies, wild oat showed high responsiveness to $\mathrm{N}$ and medium responsiveness to $\mathrm{P}$, relative to wheat's low responsiveness to both nutrients (Blackshaw et al. 2003, 2004), but competition between the two species was unaffected by varying rate of $\mathrm{N}$ or $\mathrm{P}$ (Blackshaw and Brandt 2008, 2009).

\section{Crop-Weed Competition: How Does Fertility Rate Affect Yield of Weedy Crops?}

Studies have reported varying effects of fertility on competition between weeds and crops. For example, in one study yield of irrigated corn increased with $\mathrm{N}$ rate despite increasing Palmer amaranth (Amaranthus palmeri S. Wats.) biomass (RufPachta et al. 2013) whereas in another study compost addition decreased yield of corn competing with velvetleaf (Abutilon theophrasti Medik.) that had emerged shortly after the crop (Liebman et al. 2004). What explains such disparate results? Many variables, such as weed density, species' nutrient response curves, and the relative 
time of emergence of the weed and the crop, interact to determine whether added fertility will increase, decrease, or have no effect on the yield of a crop in competition with one or more weeds. Here we categorize several of these variables into a conceptual framework, and then use this framework to explain some of the differing results reported in the literature.

Conceptual Framework. The following conceptual framework describes potential scenarios which could explain observed effects of fertility addition on the yield of a crop in competition with a single weed species. These scenarios also apply when the crop is in competition with multiple weeds having similar key characteristics (e.g. nutrient response curve, maximum height). The framework is relevant to addition of a single nutrient or an amendment containing multiple nutrients.

The presence of weeds nearly always decreases crop growth and yield relative to yield under weed-free conditions (Cousens 1985). The purpose of this conceptual framework is to explain variation in crop response to fertility in the presence of weed competition. In a given study, crop yield may be low at all fertility rates when the crop is competing with weeds relative to crop yield under weed-free conditions, but within weed-competition treatments yield may still vary with fertility rate. This variation in crop yield within weedy treatments is the focus of this conceptual framework.

Additionally, a crop's nutrient response curve may not be the same for total biomass and yield. In one study, dry bean (Phaseolus vulgaris L.) biomass was increased by most combinations of $\mathrm{N}, \mathrm{P}$, and $\mathrm{K}$, but bean grain yield was less 
responsive (Ugen et al. 2002). Where yield and biomass responses are different, the framework below focuses on the effects of fertility rate on crop yield.

The conceptual framework is divided into four competition scenarios, which are further subdivided into specific cases. Scenario 1 (Table 1.2), includes cases in which crop-weed competition is unaffected by the added nutrient. Under these circumstances, increasing fertility amendment rates may or may not affect yield, but will not affect weed competitiveness against the crop. Scenario 1a: If neither the crop nor the weed is limited by the added nutrient, then nutrient rate will affect neither crop-weed competition nor crop yield. This includes cases where the lowest application rate is sufficient for maximum growth. A series of lower rates of the nutrient might show increasing growth, but the nutrient is not limiting over the nutrient application rates used in the experiment. Scenario $1 \mathrm{~b}$ and 1c: If the weed is not able to significantly affect crop yield, then the responsiveness of the weed to fertility is irrelevant. In these cases, whether crop yield increases with rate is entirely dependent on whether the crop is limited by the added nutrient; fertility rate and weed competition do not interact to affect crop yield differently at different rates. In Scenario $1 \mathrm{~b}$, the crop is not limited by the added nutrient, so yield is unresponsive to fertility rate. In Scenario 1c, the crop is limited by the added nutrient, so yield increases with fertility rate. The case in which crop yield is limited by fertility and weed growth is not might at first glance appear to belong in Scenario 1, but if crop growth increases with rate and weed growth does not, then the crop will become more competitive with increasing fertility. This case will be discussed in later Scenarios in 
which crop-weed competition is affected by fertility rate (Scenarios 2a, 3a, 3b, and 4a).

Table 1.2: Scenario 1 - crop and weed competition is unaffected by the added nutrient

\begin{tabular}{ll}
\hline Situation & Yield response \\
\hline a. & Neither crop nor weed is limited by \\
the added nutrient - limitation is by & Yield is unaffected by rate \\
water or some other nutrient & \\
b. $\begin{array}{l}\text { Crop is not limited by the added } \\
\text { nutrient; weed is limited, but is poor } \\
\text { competitor due to inherently slow } \\
\text { growth, late emergence, low density }\end{array}$ & Yield is unaffected by rate \\
etc. & \\
c. $\begin{array}{l}\text { Crop is limited by the added nutrient; } \\
\text { weed is limited, but is poor }\end{array}$ & Yield increases \\
competitor due to inherently slow \\
growth, late emergence, low density \\
etc.
\end{tabular}

Scenario 2 (Table 1.3), applies to situations in which no strong asymmetric competition for light occurs; neither the weed nor the crop overtops the other at high nutrient rates. The stipulation that asymmetric competition is minimal implies that competitive ability has the same constant of proportionality to productivity at all rates (Weiner 1990). In Scenario 2a, crop growth is more or equally responsive than weed growth to increasing fertility rate. In this case, weed competitive ability at the highest rate is irrelevant because even if weed growth increases with rate, crop growth will increase in at least the same proportion, resulting in an incremental yield increase with increasing fertility rate. In Scenarios $2 b, 2 c$, and $2 d$, weed growth is more responsive than crop growth to fertility rate and thus yield response to rate is dependent on the weed's competitive ability. If the weed is a strong competitor (2b), then the increasing 
weed growth in response to fertility rate will outweigh any benefit of the added fertility, and yield will decrease with rate. If the weed is a poor competitor (2d), then crop yield will increase with rate because even though the weed's biomass and thus competitive ability increases with rate, it does not increase enough to counteract the yield increase due to added fertility. This represents a rare but interesting case. An example might be common chickweed (Stellaria media (L.) Vill.) competing with corn. Corn quickly overtops common chickweed, but chickweed is shade tolerant (Sobey 1981) and its growth is thus not necessarily suppressed. In fact, the moderate temperatures and decreased moisture stress under the corn canopy can even benefit the chickweed during hot, dry weather (Mohler, pers. obs.). Even if chickweed growth were highly responsive to fertility of a given nutrient, its biomass is so small relative to corn that any effect of increasing fertility rate on chickweed-corn competition would be negligible. Scenario $2 \mathrm{c}$, represents a gray area intermediate between $2 \mathrm{~b}$ and $2 \mathrm{~d}$. In this case, weed growth is more responsive than the crop to fertility rate but the weed and the crop are so well matched competitively that increasing fertility rate increases yield loss due to weed competition and yield increases gain due to added fertility, resulting in no net effect on yield of increasing fertility rate. This case should be mathematically unlikely, but because field research data are often subject to many sources of error and variability and because statistical methods are biased against false positives, slight positive or negative yield trends may not be statistically significant. This results in more examples of Scenario 2c than would otherwise be expected. 
Table 1.3: Scenario 2-no strong asymmetric competition for light. Assumes crop yield is limited by the added nutrient. See table 1.2 for cases in which the crop is not limited by the added nutrient.

\begin{tabular}{llll}
\hline Response curves & $\begin{array}{l}\text { Weed competitive } \\
\text { ability at high rate }\end{array}$ & Yield response to rate \\
\hline a. & $\begin{array}{l}\text { Crop more or } \\
\text { equally responsive }\end{array}$ & Irrelevant & Yield increases \\
b. $\begin{array}{l}\text { Weed more } \\
\text { responsive }\end{array}$ & $\begin{array}{l}\text { Weed strong } \\
\text { competitor }\end{array}$ & Yield decreases \\
c. $\begin{array}{l}\text { Weed more } \\
\text { responsive }\end{array}$ & $\begin{array}{l}\text { Weed moderate } \\
\text { competitor }\end{array}$ & Yield unaffected \\
d. Weed more & $\begin{array}{l}\text { Weed poor } \\
\text { responsive }\end{array}$ & Yield increases \\
\hline
\end{tabular}

Scenario 3 (Table 1.4), includes situations in which strong asymmetric competition for light does not occur until canopy closure. After canopy closure, either the weed or the crop continues to grow above the canopy of the other, resulting in asymmetric competition. In Scenario 3a, yield increases with fertility rate because the crop's maximum height is greater than that of the weed and the increasing fertility rate increasingly enables the crop to attain that maximum height. In Scenario 3b, increasing fertility benefits crop growth more than or equally to weed growth, but the weed's maximum height is greater. In this case, any pattern of yield response to fertility rate is possible depending on how rate affects the competitive ability of the crop and the weed. For example, if the weed's growth is not responsive to fertility rate, its competitive ability will not vary with fertility rate, and thus the more responsive crop will benefit from increasing fertility. However, if the crop and the weed are similarly responsive to fertility, then the weed's ability to shade the crop at and after canopy closure would increase with fertility rate. In this case, yield might be 
unresponsive to fertility rate or might decrease with fertility rate due to the increasing weed competition. Scenario $3 c$ is the same as Scenario $3 b$, but with the characteristics of the crop and weed reversed. Any pattern of yield response to fertility rate is possible for the similar reasons as in $3 \mathrm{~b}$. In Scenario $3 \mathrm{~d}$, yield will decrease with added fertility because increasing fertility will increasingly enable the weed to overtop the crop at canopy closure. If the weed is present at densities high enough to affect crop yield (i.e., Scenario $1 \mathrm{a}$ or $1 \mathrm{~b}$ do not apply), then added fertility will benefit the weed to the detriment of crop yield.

Table 1.4: Scenario 3 - symmetric competition for light before canopy closure, asymmetric competition afterwards. Assumes crop yield is limited by the added nutrient. See table 1.2 for cases in which the crop is not limited by the added nutrient.

\begin{tabular}{lll}
\hline Response curves & Relative stature & Yield response \\
\hline $\begin{array}{l}\text { a. } \\
\text { equally } \\
\text { responsive }\end{array}$ & Crop taller & Yield increases \\
b. $\begin{array}{l}\text { Crop more or } \\
\text { equally } \\
\text { responsive }\end{array}$ & Weed taller & $\begin{array}{l}\text { Any pattern is possible depending on } \\
\text { how competitive ability of the crop and } \\
\text { the weed change with rate. }\end{array}$ \\
c. $\begin{array}{l}\text { Weed more } \\
\text { responsive }\end{array}$ & Crop taller & $\begin{array}{l}\text { Any pattern is possible depending on } \\
\text { how competitive ability of the crop and } \\
\text { the weed change with rate. } \\
\text { Yield decreases }\end{array}$ \\
d. $\begin{array}{l}\text { Weed more } \\
\text { responsive }\end{array}$ & Weed taller & \\
\hline
\end{tabular}

Scenario 4 (Table 1.5), applies to situations in which strong asymmetric competition for light occurs at or before canopy closure. Either the weed or the crop is able, at high nutrient application rates, to suppress the other by overtopping and shading to such an extent that the greater potential relative height of the lessor 
competitor cannot be realized. Such cases are probably rare as they require close spacing of a highly competitive crop or an extremely high weed density. In Scenario $4 a$, yield increases with rate regardless of the outcome of competition at low rates or which species is more responsive to rate because the increasing fertility increases the crop's ability to suppress the weed. In Scenario 4b, yield increases with rate up to a point, and then decreases as fertility is added beyond that point. This might happen if a highly competitive weed is able to take advantage of higher fertility rates than the crop, but is more limited by low fertility than the crop. In this case, crop growth would increase more quickly than weed growth with added fertility at the low rates, improving the crop's yield. At higher rates crop response to fertility levels off while weed growth continues to increase with added fertility, resulting in greatly increased weed competition and decreased yield. This yield response curve would also be observed in Scenario 4c. At low fertility rates, neither the crop nor the weed can grow large enough to suppress the other asymmetrically. Thus at low rates competition is the same as in Scenario 2 and if the crop is at least as responsive to fertility as the weed then yield will increase with rate until the point at which enough nutrients are supplied to allow the weed to outgrow and suppress the crop. Thereafter, yield decreases with fertility rate. However, if neither are suppressed at low rates and the weed is more responsive to fertility than the crop (Scenario 4d), then at low rates competition is as in Scenario $2 b$, and yield decreases with rate due to increased symmetric competition from the weed. And at high rates the weed is able to outgrow and asymmetrically suppress the crop, so yield decreases continuously with increasing 
rate. Similarly in Scenario 4e, yield decreases with increasing fertility if the weed is increasingly able to suppress the crop from low to high fertility rates.

Table 1.5: Scenario 4-strong asymmetric competition for light by the time of canopy closure. Assumes crop yield is limited by the added nutrient. See table 1.2 for cases in which the crop is not limited by the added nutrient.

\begin{tabular}{|c|c|c|c|}
\hline $\begin{array}{l}\text { Competition for } \\
\text { light at high rates }\end{array}$ & $\begin{array}{l}\text { Competition for } \\
\text { light } \\
\text { at low rates }\end{array}$ & Response curves & $\begin{array}{l}\text { Yield response to } \\
\text { rate }\end{array}$ \\
\hline $\begin{array}{ll}\text { a. } & \text { Crop } \\
\text { suppresses } \\
\text { weed }\end{array}$ & Irrelevant & Irrelevant & Yield increases \\
\hline $\begin{array}{l}\text { b. Weed } \\
\text { suppresses crop }\end{array}$ & $\begin{array}{l}\text { Crop suppresses } \\
\text { weed }\end{array}$ & Irrelevant & $\begin{array}{l}\text { Yield goes up, } \\
\text { then down }\end{array}$ \\
\hline $\begin{array}{l}\text { c. Weed } \\
\text { suppresses crop }\end{array}$ & Neither suppressed & $\begin{array}{l}\text { Crop more or } \\
\text { equally responsive }\end{array}$ & $\begin{array}{l}\text { Yield goes up, } \\
\text { then down }\end{array}$ \\
\hline $\begin{array}{ll}\text { d. Weed } \\
\text { suppresses crop }\end{array}$ & Neither suppressed & $\begin{array}{l}\text { Weed more } \\
\text { responsive }\end{array}$ & Yield decreases \\
\hline $\begin{array}{l}\text { e. Weed } \\
\text { suppresses crop }\end{array}$ & $\begin{array}{l}\text { Weed suppresses } \\
\text { crop }\end{array}$ & Irrelevant & Yield decreases \\
\hline
\end{tabular}

Applying the Framework to Research Findings. The above conceptual framework can be used to better understand what conditions lead to the variable results obtained in published studies on the effects of fertility on weed-crop competition. These conditions include availability of other potentially limiting resources, maximum stature of the crop and the weed, relative emergence times of the crop and the weed, responsiveness to fertility rate of crop and weed growth and competitive ability.

Some examples of crop yield failing to respond to fertility addition can be explained by conditions within Scenario 1 (Table 1.2). Several studies have reported that in at least one site-year, water was more limiting than the added nutrient for both 
the crop and the weed (Scenario 1a: Ball et al. 1996; Blackshaw et al. 2000; RufPachta et al. 2013; Ugen et al. 2002). In other cases, weed growth responded to added fertility, but late weed emergence relative to the crop prevented the weed from significantly affecting crop yield. For example, Menalled et al. (2004) found that although soybean (Glycine max (L.) Merr.) yield did not increase with compost addition, soybean over-topped common waterhemp (Amaranthus rudis Saur.) when the weed was planted after soybean, regardless of the weed's response to compost addition. Liebman et al. (2004) reported similar effects of compost addition on competition between corn and velvetleaf that emerged several days after the crop. Emergence times did not vary between compost treatments. Corn yield did not increase with compost addition, presumably because sufficient fertility was available from the soil without compost amendment. Yield was significantly reduced by the presence of weeds and weed biomass did increase with compost addition. However, due to the delayed weed emergence, crop yield was similar regardless of compost treatment, despite the increased weed biomass with compost addition. In another study, neither dry bean yield nor wild mustard (Sinapis arvensis L.) growth responded to the added fertility amendment (Scenario 1a: Liebman and Gallandt 2002).

The lack of a crop yield response to added fertility can also be a result of the added nutrient benefitting the weed more than the crop (Scenario 2c). For example, Mesbah and Miller (1999) reported that broadcast application of $45 \mathrm{~kg} \mathrm{~N} \mathrm{ha}^{-1}$ significantly increased winter wheat yield when grown weed-free but that yield was unaffected by $\mathrm{N}$ addition when the wheat competed with jointed goatgrass (Aegilops cylindrica Host.), a winter annual. The $\mathrm{N}$ significantly increased jointed goatgrass 
height. The weed remained shorter than the crop but still caused increased weed pressure resulting in no response in wheat yield or height to the added N (Scenario 2c). Barker et al. (2006) reported similar results with varying rates of N. Although corn yield was limited by $\mathrm{N}$ in the weed-free control, yield failed to respond to increasing $\mathrm{N}$ rates when in competition with velvetleaf which had emerged shortly after the corn. Although velvetleaf pressure decreased corn yield, the weed's height never surpassed that of corn. In this study, increasing competition from the velvetleaf was apparently sufficient to cancel the potential increase in corn growth in response to rising rates of N (Scenario 2c). Blackshaw and Molnar (2009) found similar results in competition experiments with spring wheat and three weed species, though the causal factors varied. A broadcast application of $18 \mathrm{~kg} \mathrm{P} \mathrm{ha}^{-1}$ significantly increased spring wheat yield under weed-free conditions, but not when the wheat was grown with redstem filaree (Erodium cicutarium (L.) L’Hér. Ex Ait.), wild mustard, or wild oat. Both redstem filaree and wild mustard were more responsive to $\mathrm{P}$ addition than wheat. Redstem filaree was able to prevent an increase in wheat yield with fertilization despite its prostrate habit, suggesting that competition was symmetric (Scenario 2c). This may have been the case with wild mustard as well, depending on what height it reached in this study. In both cases, the weed's higher responsiveness to the $\mathrm{P}$ prevented the additional fertility from producing the yield increase observed in the weed-free control. Spring wheat and wild oat were similarly responsive to $\mathrm{P}$, but due to wild oat's ability to over-top modern short-statured wheat varieties after canopy closure (Cudney et al. 1991), the added P probably increased asymmetric competition against the crop after it reached its maximum height (Scenario 3b). 
An increase in yield with fertility rate can be unaffected by weed competition if the weed density is low (Scenario 1c). For example, in one particularly dry year, yield of spring wheat competing with the perennial weed foxtail barley (Hordeum jubatum $\mathrm{L}$.) increased with $\mathrm{N}$ rate in a tilled treatment but not in a no-till treatment (Blackshaw et al. 2000). Foxtail barley's growth was highly responsive to $\mathrm{N}$ rate in no-till, but was unaffected by $\mathrm{N}$ in the tilled treatment due to reduced density. This enabled wheat to respond to increasing $\mathrm{N}$ in the tilled treatment.

Yield increasing with fertility application rate can also be due to the crop benefiting from the added nutrients despite increased competition from the weed. This can occur when competition between the crop and weed is symmetric and the crop is equally or more responsive to the added nutrient (Scenario 2a). For example, RufPachta et al. (2013) reported that, when irrigated, corn and Palmer amaranth growth were similarly responsive to increasing $\mathrm{N}$ rate. Thus both benefitted equally from the added $\mathrm{N}$ and crop yield increased with rate despite increasing weed competition. Even if the weed is more responsive to the added nutrient, crop yield may still increase with nutrient rate if the weed is a poor competitor. For example, Santos et al. (2004a) showed that presence of common purslane (Portulaca oleracea L.) significantly reduced lettuce yield (Lactuca sativa L.), despite its prostrate habit. Additionally, common purslane biomass increased more with $\mathrm{P}$ than lettuce biomass. However, lettuce yield increased with $\mathrm{P}$ despite the increased growth of purslane, probably because purslane's prostrate habit meant that the weed's competitive ability did not increase proportionally to its increased biomass (Scenario 3c). 
An increase in crop yield with added fertility can be partly due to the crop's competitive ability increasing with added fertility. This may occur if crop growth increases with rate but weed growth does not. For example, Lindsey et al. (2013) found that potato (Solanum tuberosum L.) vine mass and tuber yield increased with compost rate (added $\mathrm{P}, \mathrm{K}$, and micronutrients). Growth of the weeds giant foxtail (Setaria faberi Herrm.), common lambsquarters (Chenopodium album L.), and hairy nightshade (Solanum physalifolium Rusby) was unresponsive to compost rate. Although the weeds over-topped the crop toward the end of the season, the crop was already senescing by this point and weed-crop competition was symmetric during the stage when potato tubers developed (Scenario 2). Before senescence, potato biomass increased with increasing compost rate, making the crop increasingly competitive (Scenario 2a). Similarly, Santos et al. (2004a) found that lettuce growth increased with $\mathrm{P}$ rate despite competition from the inherently taller weed smooth amaranth (Amaranthus hybridus L.) because the weed's growth was unresponsive to $\mathrm{P}$ addition (Scenario 3b).

In two other studies, crop yield increased with fertility rate when the crop emerged before the weed (Andreasen et al. 2006; Blackshaw and Molnar 2009). In both studies, the cold-tolerant crop gained an early-season advantage against the weed and that advantage was further increased by the added fertility (Scenario 4a).

Finally, nutrient addition can have negative effects on crop yield if the added nutrient benefits the weed more than the crop. In addition to the corn vs. velvetleaf study described earlier (Liebman et al. 2004), a related study reported that compost addition decreased soybean yield when common waterhemp was sown at or shortly 
after soybean planting (Menalled et al. 2004). The added compost enhanced the common waterhemp's ability to overtop and shade the soybean, thereby increasing asymmetric competition against the crop (Scenario 3d). In a weed-free check, soybean yield did not respond to compost amendment. Thus the compost addition benefitted only the weed, to the detriment of soybean yield. In another study, increasing $\mathrm{N}$ rate increased radish (Raphanus sativus L.) yield in the weed-free control, but reduced yield when radish was grown with purple nutsedge (Cyperus rotundus L.) (Santos et al. 1998). The purple nutsedge grew faster than the radish and quickly shaded the crop. This shading ability was likely enhanced by $\mathrm{N}$ addition, which significantly increased purple nutsedge biomass (Scenario $4 \mathrm{~d}$ or $4 \mathrm{e}$ ). However, all three studies used only extremely high nutrient rates. Liebman et al. (2004) and Menalled et al. (2004) chose compost rates much higher than would normally be used by growers $(4,000$ to 8,000 $\mathrm{kg} \mathrm{C} \mathrm{ha}{ }^{-1}$ ) to ensure a rapid, significant increase in soil nutrient concentrations. Santos et al. (1998) used $\mathrm{N}$ rates so high (up to $330 \mathrm{~kg} \mathrm{~N} \mathrm{ha}^{-1}$ ) that at the highest rates radish exhibited $\mathrm{N}$ toxicity symptoms. The effect of fertility on crop-weed competition might have been different at lower rates (see Scenario 4c). A wider range of fertility rates, from below to above recommended levels, would be required to test this hypothesis.

Crop Competition with Multiple Weeds. Fewer recent studies have examined the effect of fertility rate on competition between a crop and a mixture of weed species. This weed-crop situation warrants more study because crop competition from multiple weed species is more realistic of many field conditions than competition between a crop and a single weed species. 
A diverse weed community is likely to include at least one species that is both a strong competitor and highly responsive to fertility. The typical, high fertility amendments commonly used in agriculture may increase the prevalence of weed species which are both adapted to respond to fertility and are most competitive under high-fertility conditions (Grime and Hunt 1975). Thus, if a crop is competing against a functionally diverse weed community then yield will only benefit from increasing fertility rate if the crop is limited by the added nutrient and at least one of the following conditions is true: (1) weed competitiveness is limited by low density, effective weed control, or late emergence (2) none of the weed species present is as responsive to fertility as the crop, (3) the crop is highly responsive to fertility and tall statured, or (4) the crop is able to exert strong asymmetric competition by canopy closure against all species, at least at the high rate. These conditions are drawn from the scenarios described in the conceptual framework used above to explain effects of competition with one weed on yield response to fertility.

For example, one field study tested the effect of $\mathrm{P}$ rate on yield of corn competing against redroot pigweed, large crabgrass (Digitaria sanguinalis (L.) Scop.), barnyardgrass (Echinochloa crus-galli (L.) Beauv.), and common lambsquarters (Vengris et al. 1955). In the weed-free treatment, corn yield response to $\mathrm{P}$ was not statistically significant in either of the two years. In contrast, the biomass of all four weeds, when grown without corn, increased significantly with $\mathrm{P}$ application rate. When corn and weeds were grown together, in one year corn yield response to $\mathrm{P}$ was not significant, whereas in the second year (on a new field plot) corn yield decreased with increasing P. In this study, the crop was not limited by the added nutrient, 
presumably because sufficient $\mathrm{P}$ for maximum corn growth was supplied by the soil and the sod plowed down before planting (condition 2, above, does not apply). Thus corn yield could not benefit from $\mathrm{P}$ addition, but weed growth did benefit, so much so in the second year that corn yield actually decreased with $\mathrm{P}$ application rate (Vengris et al. 1955).

Results from two studies showed increasing wheat yield with $\mathrm{N}$ rate despite competition from multiple weeds (Anderson et al. 1998; Juroszek et al. 2004). Both cases are examples of condition 4, where fertility addition aids the crop's ability to asymmetrically shade the weeds. In a no-till rotation of spring wheat, winter wheat, and sunflower (Helianthus annuus L.), yield of all three crops increased with broadcast $\mathrm{N}$ rate when competing with the naturally occurring weed community. The most common species were green foxtail (Setaria viridis (L.) Beauv.), yellow foxtail (Setaria pumila (Poir.) Roemer \& J.A. Schultes), kochia (Kochia scoparia (L.) Schrad.), and Russian thistle (Anderson et al. 1998). Density of these weeds decreased with $\mathrm{N}$ rate (from 142 to 58 weeds $\mathrm{m}^{-2}$ ) suggesting that wheat competitive ability against these weeds increased with $\mathrm{N}$ rate. Another study used a winter wheat cultivar ('Pegassos') that has been selectively bred for competitive ability (Juroszek et al. 2004). In all three site-years, grain yield and shading ability of 'Pegassos' winter wheat increased with addition of an organic $\mathrm{N}$ amendment (horn meal or fermented molasses). Ground cover of common chickweed, silky windgrass (Apera spica-venti (L.) Beauv.), and Italian ryegrass (Lolium perenne (L.) ssp. multiflorum (Lam.) Husnot) was significantly increased by $\mathrm{N}$ addition, whereas ground cover of catchweed bedstraw (Galium aparine L.), hairy vetch (Vicia hirsuta L.), and volunteer 
alfalfa (Medicago sativa L.) was not significantly affected by $\mathrm{N}$ addition. However, $\mathrm{N}$ addition improved the wheat's ability to asymmetrically shade all of these weeds, thereby allowing the increased yield with application of the fertilizer.

Odero et al. (2013) reported similarly improved competitive ability and yield in lettuce fertilized with increasing rates of broadcast $\mathrm{P}$. This study did not report the effect of $\mathrm{P}$ application rate on growth of the most common weeds present: common lambsquarters, smooth pigweed, goosegrass (Eleusine indica (L.) Gaertn.), and yellow nutsedge (Cyperus esculentus L.). If weed growth did not respond to $\mathrm{P}$ application rate, then this might be an example of condition 2, where the crop benefits from increasing fertility because it is more responsive to the added nutrient than the weeds. However, the information provided does not allow explanation of the lettuce yield results using the conceptual framework proposed in this review.

Future research on the effect of fertility on crop-weed competition will help elucidate the mechanisms and variables that explain the varying results. Important data to collect in these studies include crop and weed emergence dates, relative height of crop at canopy closure and at harvest, weed density, most common and largest weeds present when a natural community of weeds is used, weed growth response to fertility, crop yield response to fertility in a series of weed-free controls, and yield response to a wide range of fertility application rates including inherent soil fertility (no added fertility) as a control. A control treatment with no added fertility is important to include in both the weed-free and weedy-treatments, because it enables the researcher to determine whether a lack of yield response to fertility application rate is due to 
weed competition or to sufficient nutrient supply from the soil enabling for maximum crop yield.

\section{Management: How Can Fertility Management Reduce the Impact of Weeds?}

Much research has been devoted to the possibility of adjusting fertility management to benefit the crop more and benefit the weeds less. Such research has focused on manipulation of three variables: nutrient placement, timing of nutrient supply, and nutrient source.

Placement. Because crops are planted in predictable locations and weeds are semirandomly distributed, nutrients can be placed in locations that maximize the probability that the crop's roots will intercept them before the roots of a weed. In his review, Di Tomaso (1995) reported that applying fertility amendments in a band near the crop row either increased yield or had no effect on yield but reduced weed growth in seven published studies. Similar results were obtained in more recent studies. When spring wheat was grown with green foxtail or wild mustard, yield was improved by point injecting $\mathrm{N}$ between every other row, compared with broadcast applying $\mathrm{N}$ (Blackshaw et al. 2002). Similarly, Kirkland and Beckie (1998) found that spring wheat in competition with a natural weed community had higher yield and reduced weed pressure when $\mathrm{N}$ was side-banded at seeding between every other row, compared with broadcast $\mathrm{N}$. In winter wheat, applying $\mathrm{N}$ in a band below the seed decreased density of downy brome (Bromus tectorum L.) and increased wheat biomass but not grain yield, compared with broadcast $\mathrm{N}$ application (Rasmussen 1995). 
Mesbah and Miller (1999) found that the effect of jointed goatgrass on wheat yield was reduced when $\mathrm{N}$ was either banded $5 \mathrm{~cm}$ below and $2.5 \mathrm{~cm}$ to the side of the seed or injected $5 \mathrm{~cm}$ away from the row and $10 \mathrm{~cm}$ deep, compared with broadcast $\mathrm{N}$ application. Santos et al. (2004b) reported that lettuce yield loss to common lambsquarters was reduced by banding $\mathrm{P}$ beneath the lettuce row, rather than broadcast application of $\mathrm{P}$.

Vertical fertility placement can also affect crop competitive ability and weed growth. Deep injection of liquid fertilizers may benefit weed control in deep-rooted crops such as barley, even when injection is done before planting and injection rows are not necessarily spatially aligned with crop rows (Rasmussen 2002). Juroszek et al. found that incorporating organic $\mathrm{N}$ sources (horn meal or fermented molasses) reduced growth of common chickweed, compared with surface applications.

Due to the overwhelming evidence that targeting fertility placement to crop location reduces weed growth and competition, future work should include the economic impact of fertilizer placement and address questions such as: "Under what circumstances would increased crop yield due to reduced weed competition and decreased cost of fertilizer use due to lower recommended rates when banding, offset the cost of the banding equipment?" Similarly, "are the benefits in weed management sufficient to justify purchase of equipment and the extra fuel required to place fertility considerably deeper than the conventional $5 \mathrm{~cm}$ below the seed?" Finally, "How do weed species and weed density affect these cost-benefit analyses?" 
Timing. The goal of studying the effect of timing of nutrient supply on crop-weed competition is to determine peak nutrient release for various nutrient sources and time of peak nutrient requirement by crops. This information can be used to design best management practices that place the release peak at a time that most benefits the crop rather than the weeds (Di Tomaso 1995). A study by Angonin et al. (1996) successfully applied this concept to competition between winter wheat and the winter annual weed ivyleaf speedwell (Veronica hederifolia $\mathrm{L}$.). When $\mathrm{N}$ was applied at the tillering stage of winter wheat growth, yield decreased significantly with increasing ivyleaf speedwell density. However, when $\mathrm{N}$ was applied later at the wheat stem elongation stage, ivyleaf speedwell density had no significant effect on wheat yield. This result was attributed to a reduction in weed growth in the early spring, the time when ivyleaf speedwell is most competitive. In contrast, when $\mathrm{N}$ was applied to high ivyleaf speedwell density treatments at wheat stem elongation, the wheat compensated for the effects of early season weed competition by increasing individual grain weight (Angonin et al. 1996).

However, delayed fertility application does not always benefit crop yield. For example, Johnson et al. (2007) found that neither corn grain yield nor the effect of giant ragweed (Ambrosia trifida $\mathrm{L}$.) on corn grain yield varied with $\mathrm{N}$ application timing. However, because later $\mathrm{N}$ application timings reduced corn leaf area and increased that of giant ragweed, at higher weed densities early $\mathrm{N}$ application timings might be beneficial to corn competitive ability and yield. Dhima and Eleftherohorinos (2001) obtained similar results with sterile oat (Avena sterilis L.) in winter wheat, triticale, and barley. In winter barley, sterile oat was a poor competitor regardless of $\mathrm{N}$ 
application timing. In winter wheat or triticale (x Triticosecale rimpaui Wittm.), sterile oat was highly competitive, but this competitiveness was only marginally affected by timing of nutrient supply. If anything, sterile oat competition was greater with split applications of $50 \mathrm{~kg} \mathrm{~N} \mathrm{ha}^{-1}$ before planting and $100 \mathrm{~kg} \mathrm{~N} \mathrm{ha}^{-1}$ at tillering compared with a lump application of $150 \mathrm{~kg} \mathrm{~N} \mathrm{ha}^{-1}$ before planting (Dhima and Eleftherohorinos (2001). Terry et al. (2012) reported that interference of volunteer corn in hybrid corn was increased by late-season $\mathrm{N}$ applications, but this is an unusual case because increased grain yield from volunteer corn can, to a certain extent, compensate for lost hybrid corn yield.

Ball et al. (1996) found that downy brome growth and competitiveness was highly responsive to $\mathrm{N}$ applied at any point during the growing season. Applying $\mathrm{N}$ at planting or during the growing season increased yield of weed-free winter wheat over the common practice of applying $\mathrm{N}$ in the preceding bare fallow. But when winter wheat was infested with downy brome, yield did not benefit from $\mathrm{N}$ application at planting or in-crop and downy brome biomass increased. These results mirror those of earlier studies of the effect of timing of $\mathrm{N}$ supply in winter wheat competing with downy brome (Anderson 1991; Wicks 1984). Wheat yield benefits from $\mathrm{N}$ application during fallow because $\mathrm{N}$ applied at this time leaches below downy brome's shallow rooting zone before the growing season begins. Wheat, with its deeper roots, can then access the $\mathrm{N}$ more easily than downy brome, the roots of which rarely grow deeper than $33 \mathrm{~cm}$ (Anderson 1991). However, $\mathrm{N}$ applied during fallow may leach further into groundwater, motivating the Ball et al. (1996) study of in-season $\mathrm{N}$ application timings. Future studies might test whether injecting $\mathrm{N}$ at a range of depths could 
mimic the benefit of $\mathrm{N}$ application during fallow, reducing downy brome access to $\mathrm{N}$. Injecting $\mathrm{N}$ can also increase $\mathrm{N}$ leaching to groundwater, so such a study could also compare the effect on groundwater of injecting $\mathrm{N}$ in-season and surface-applying $\mathrm{N}$ in fallow.

Source. The source in which nutrients are supplied can affect weed growth through differences in a species' preference for certain chemical forms, the rate of nutrient mineralization and availability, the ratios of nutrients (e.g N:P) supplied within a single source, and other qualities of the fertility amendment independent of the supplied nutrients.

Ammonium and nitrate vary in metabolic cost to plants of uptake and assimilation (Bloom et al. 1992), effect on soil pH (Thomson et al. 1993), and mobility in soil solution. These differences may lead to variation in uptake and growth responses of crops and weeds supplied with $\mathrm{NO}_{3}{ }^{-}$or $\mathrm{NH}_{4}{ }^{+}$. For example, Teyker et al. (1991) found that although corn growth was equally responsive to $\mathrm{NO}_{3}{ }^{-}$or $\mathrm{NH}_{4}{ }^{+}$, redroot pigweed growth was significantly more responsive to $\mathrm{NO}_{3}{ }^{-}$than to $\mathrm{NH}_{4}{ }^{+}$when it was applied with a nitrification inhibitor. Another study found that giant foxtail growth did not vary between $\mathrm{NH}_{4}{ }^{+}$(with a nitrification inhibitor) and $\mathrm{NO}_{3}{ }^{-}$treatments (Salas et al. 1997). However, at the highest rate seed production was reduced when $\mathrm{N}$ was supplied as $\mathrm{NH}_{4}{ }^{+}$with a nitrification inhibitor. If differences between crops and weeds in affinity for nutrient form can be capitalized on, $\mathrm{N}$ fertility amendments and additives might be tailored to minimize benefits to weeds. 
Conventional and organic fertility amendments tend to differ in the timing of nutrient availability, because organic fertility amendments require time to decompose before they can release nutrients into the soil solution. Delayed nutrient supply from organic fertility amendments has been observed in green manures (Dyck et al. 1995) and composted livestock manure (DeLuca and DeLuca 1997). However, depending on placement and moisture, organic amendments can supply nutrients quickly (LunaOrea et al. 1996). As research progresses on timing of nutrient supply from organic fertility amendments and the effect of fertility availability timing on weed-crop competition, delayed nutrient supply from organic sources may become a valuable tactic of integrated weed-fertility management.

However, weed growth has been shown to respond to organic fertility amendments (Juroszek et al. 2004; Little et al. 2013), sometimes to the detriment of crop yield (Liebman et al. 2004; Menalled et al. 2004). In some cases, this response may be due to an imbalance between crop nutrient needs and nutrients applied in the amendment. When compost or manure is applied at rates estimated to meet $\mathrm{N}$ needs, other nutrients, including P, are commonly oversupplied because nutrient ratios (e.g. $\mathrm{N}: \mathrm{P}$ ) in compost and manure are fixed (Eghball and Power 1999). This can result in both over-fertilization within a single season and a gradual elevation of soil fertility levels over time (Hart et al. 1997). If more responsive weeds are able to take advantage of this additional fertility (Little et al. 2013), higher weed pressure can result. Reducing application rates and supplying some $\mathrm{N}$ with other sources, including green manures, might help reduce over-fertilization and reduce weed pressure that otherwise could result. Other possible methods for better matching nutrient ratios in 
manure and composted manure amendments to crop needs include changes in livestock feed supplements (Swink et al. 2009) and manure processing methods (Westerman et al. 2010).

Aside from weed growth response to added fertility, growers are often concerned about the introduction of weed seed in compost and manure, the number of seeds in these amendments is often low relative to the number of seeds in the soil seed bank (Mt. Pleasant and Schlather 1994). However, introduction of new weed species can be an issue (Cook et al. 2007; Mt. Pleasant and Schlather 1994).

The effects of green manures on weed growth and competition extend beyond the nutrients supplied by the decomposing green manure biomass. Some plants grown as green manure produce allelopathic chemicals that suppress the growth of other plants both when the green manure is growing and when the residue is decomposing. In laboratory bioassays, Davis and Liebman (2003) observed an allelopathic effect of soil containing red clover (Trifolium pratense L.) residue on seedlings of both giant foxtail and corn. However, only giant foxtail emergence was affected by red clover residue in the field. Additionally, weed-suppressive effects of green manure may be due to increased disease pressure. For example, Conklin et al. (2002) found that amending soil with red clover residue and compost increased Pythium spp. infection of wild mustard seedlings, while leaving corn seedlings unaffected. However, diseasepromoting effects of green manures appear to diminish quickly after incorporation. Mohler et al. (2012) found that amendment with fresh pea, oat, and weed residue promoted fatal infection of several types of weed seeds by the fungi Fusarium oxysporum and $F$. chlamydosporoum, but the reduced weed seedling emergence lasted 
for only four days after residue incorporation. In the longer term, organic fertility amendments may promote soil conditions that are more conducive to microbial activity and thus increase weed seedbank mortality (de Cauwer et al. 2011; Kremer and $\mathrm{Li} 2003)$.

\section{Directions for future research}

In the body of literature reviewed here, effects of fertility addition on cropweed competition vary from study to study and even from year to year within studies. A deeper understanding of the mechanisms which drive crop and weed response to fertility and the effect of fertility on crop-weed competition is needed to develop extension recommendations for integrating fertility and weed management. Knowing more about what leads to varying results will help make the effect of fertility addition on weed-crop competition more predictable and make the results of experimental trials more applicable to the management strategies of growers.

Recommendations for future research made above include collecting more consistent types of data across studies, to better allow comparison and interpretation. For example, reporting the relative timing of crop and weed emergence enables researchers to consider the interaction between early-season height advantage and response to fertility. Testing crop and weed response to a wide range of fertility application rates, both below and above the local recommendation and including a zero added fertility control, enables construction of nutrient response curves. These can aid in identifying optimal fertility amendment rates for weedy crops, which may differ from optimal rates expected based on the assumption of weed-free conditions. 
Studying the effects of fertility addition on competition between a crop and a single type of weed enables one to limit the number of variables and focus on how fertility influences crop-weed competitive relationships. This is important for understanding the variables that drive response to fertility, such as the relative growth rates of the competing species, height hierarchies, and shading ability. Competition between a crop and a single type of weed is also realistic to conditions on farms where most competitive pressure comes from one type of weed. However, on others farms a crop may face competition from a diverse community of weeds, with a wide variety of competitive strategies and responses to fertility. Future studies will be needed to determine whether and how the effects of fertility addition on weed-crop competition vary when the crop competes with a functionally diverse weed community.

Advances in methods for studying root growth may prove useful in future studies of fertility placement. Computer software is now available to estimate root length, diameter, and surface area from scanned images of washed roots (Himmelbauer et al. 2004). This technology can greatly decrease the time required to quantitatively analyze root samples, thus facilitating comparisons of root morphology between and among crops and weeds. Minirhizotrons allow nondestructive observations of root growth and soil exploration over time in the field (Johnson et al. 2001). Use of this technology in placement studies could reveal how long it takes crop and weed roots to reach fertility amendments placed at different depths and in different locations relative to the crop row.

Finally, soil ecology is a dynamic and rapidly progressing field that offers many exciting areas for future research. Arbuscular-mycorrhizal fungi (AMF), which 
colonize the roots of many plants, play an important role in plant nutrition by effectively expanding the volume of soil a plant can access. This has a potentially large effect on availability of immobile nutrients such as P (Harley 1989; Stanley et al. 1993). Most plants can host AMF, but several important weed species and families are characterized as weak- or non-AMF-hosts (Jordan et al. 2000; Vatovec et al. 2005). These differences may play a role in the varied responsiveness to immobile nutrients among host and non-host species. Additionally, AMF populations in farm soil vary with management practices, including fertility inputs, tillage, cover crops, and crop rotations. A review by Jordan et al. (2000) called for more research on the effects of AMF on weed management. An important part of this research will be determining how AMF influence the effects of fertility management on weed growth and cropweed competitive interactions.

\section{Conclusion}

Much work has been done in recent years on the effects of fertility management on crop-weed competition. Several common problematic agronomic weeds are highly responsive to $\mathrm{N}, \mathrm{P}$, and $\mathrm{K}$ when grown in monoculture. Results of competition experiments have been varied and at times appear contradictory, but careful examination of the effect of fertility on the competitive relationship between the crop and weed can help explain some of this variation. Management studies have shown promise in manipulating fertility placement, timing, and source to reduce weed pressure. Future research in this important area of crop and weed science will help in the development and deployment of practical fertility management strategies within an 


\section{REFERENCES}

Anderson RL (1991) Timing of nitrogen application affects downy brome (Bromus tectorum) growth in winter wheat. Weed Technol 5:582-585

Anderson RL, Tanaka DL, Black AL, Schweizer EE (1998) Weed community and species response to crop rotation, tillage, and nitrogen fertility. Weed Technol $12: 531-536$

Angonin C, Caussanel JP, and Meynard JM (1996) Competition between winter wheat and Veronica hederifolia: influence of weed density and the amount and timing of nitrogen application. Weed Res 36:175-187

Ball DA, Wysocki DJ, and Chastain TG (1996) Nitrogen application timing effects on downy brome (Bromus tectorum) and winter wheat. Weed Technol 10:305-310

Barker DC, Knezevic SZ, Martin AR, Walters DT, and Lindquist JL (2006) Effect of nitrogen addition on the comparative productivity of corn and velvetleaf (Abutilon theophrasti). Weed Sci 54:354-363

Berger A, Mcdonald AJ, and Riha SJ (2007) Does soil nitrogen affect early competitive traits of annual weeds in comparison with maize? Weed Res 47:509-516

Blackshaw RE and Brandt RN (2008) Nitrogen fertilizer rate effects on weed competitiveness is species dependent. Weed Sci 56:743-747

Blackshaw RE and Brandt RN (2009) Phosphorus fertilizer effects on the competition between wheat and several weed species. Weed Biol Manag 9:46-53

Blackshaw RE, Brandt RN, Janzen HH, and Entz T (2004) Weed species response to phosphorus fertilization. Weed Sci 52:406-412

Blackshaw RE, Brandt RN, Janzen HH, Entz T, Grant CA, Derksen DA (2003)

Differential response of weed species to added nitrogen. Weed Sci 51:532-539 
Blackshaw RE and Molnar LJ (2009) Phosphorus fertilizer application method affects weed growth and competition with wheat. Weed Sci 57:311-318

Blackshaw RE, Semach G, Janzen HH (2002) Fertilizer application method affects nitrogen uptake in weeds and wheat. Weed Sci 50: 634-641

Blackshaw RE, Semach G, Li X, O'Donovan JT, and Harker KN (2000) Tillage, fertiliser and glyphosate timing effects on foxtail barley (Hordeum jubatum) management in wheat. Can J Plant Sci 80:655-660

Bloom AJ, Sukrapanna SS, and Warner RL (1992) Root respiration associated with ammonium and nitrate absorption and assimilation by barley. Plant Physiol 99:1294-1301.

Brainard DC, DiTommaso A, and Mohler CL (2006) Intraspecific variation in germination response to ammonium nitrate of Powell amaranth (Amaranthus powellii) seeds originating from organic vs. conventional vegetable farms. Weed Sci 54:435-442

Buhler DD (2002) Challenges and opportunities for integrated weed management. Weed Sci 50:273-280

Buhler DD and Hoffman ML (1999) Anderson's guide to practical methods of propagating weeds and other plants. Lawrence, KS: Allen Press 248 p.

Chapin FS (1980) The mineral nutrition of wild plants. Annu Rev Ecol Syst 11:233260

Conklin AE, Erich MS, Liebman M, Lambert D, Gallandt ER, and Halteman WA (2002) Effects of red clover (Trifolium pratense) green manure and compost soil amendments on wild mustard (Brassica kaber) growth and incidence of disease. Plant Soil 238:245-256

Cook AR, Posner JL, and Baldock JO (2007) Effects of dairy manure and weed management on weed communities in corn on Wisconsin cash-grain farms. Weed Technol 21:389-395 
Cousens R (1985) A simple model relating yield loss to weed density. Ann Appl Biol 107:239-252.

Cudney DW, Jordan LS, Bendixen WE, Holt J, Hall AE, Corbett CJ, and Reints JS (1991) Wild oat competition in short-statured wheat. Calif Agr 45:22-2e

Davis AS and Liebman M (2003) Cropping system effects on giant foxtail (Setaria faberi) demography: I. Green manure and tillage timing. Weed Sci 51:919-929

de Cauwer B, D'Hose T, Cougnon M, Leroy B, Bulcke R, and Reheul D (2011) Impact of the quality of organic amendments on size and composition of the weed seed bank. Weed Res 51:250-260

DeLuca TH and DeLuca DK (1997) Composting for feedlot manure management and soil quality. J Prod Agric 10:235-241

Dhima KV and Eleftherohorinos IG (2001) Influence of nitrogen on competition between winter cereals and sterile oat. Weed Sci 49: 77-82

Di Tomaso JM (1995) Approaches for improving crop competitiveness through the manipulation of fertilization strategies. Weed Sci 43:491-497

DiTommaso A and Aarssen LW (1989) Resource manipulations in natural vegetation: a review. Vegetatio 84:9-29

Dyck E, Liebman M, and Erich MS (1995) Crop-weed interference as influenced by a leguminous or synthetic fertilizer nitrogen source: I. Double cropping experiments with crimson clover, sweet corn, and lambsquarters. Agric Ecosyst Environ 56:93-108

Eghball B, and Power JF (1999) Phosphorus- and nitrogen-based manure and compost applications: corn production and soil phosphorus. Soil Sci Soc Am J 63:895901 
Ehleringer JR and Monson RK (1993) Evolutionary and ecological aspects of photosynthetic pathway variation. Annu Rev Ecol Syst 24:411-439

Fawcett RS and Slife FW (1978) Effects of field applications of nitrate on weed seed germination and dormancy. Weed Sci 26:594-596

Gallagher RS and Cardina J (1998) Phytochrome-mediated Amaranthus germination II: development of very low fluence sensitivity. Weed Sci 46:53-58

Grant CA, Derksen DA, Blackshaw RE, Entz T, and Janzen HH (2007) Differential response of weed and crop species to potassium and sulphur fertilizers. Can J Plant Sci 87:293-296

Grime JP and Hunt R (1975) Relative growth-rate: its range and adaptive significance in a local flora. J Ecol 63:393-422

Harbur MW and Owen MDK (2004) Light and growth rate effects on crop and weed responses to nitrogen. Weed Sci 52:57-583

Harley JL (1989) The significance of mycorrhiza. Mycol Res 92:129-139.

Hart JM, Marx ES, Christensen NW, and Moore JA (1997) Nutrient management strategies. J Dairy Sci 80:2659-2666

Himmelbauer ML, Loiskandl W, and Kastanek F (2004) Estimating length, average diameter and surface area of roots using two different image analyses systems. Plant Soil 260:111-120.

Hoveland CS, Buchanan GA, and Harris MC (1976) Response of weeds to soil phosphorus and potassium. Weed Sci 24:194-201

Hrdličková, J, Hejcman M, Křišt’álová V, and Pavlů V (2011) Production, size, and germination of broad-leaved dock seeds collected from mother plants grown under different nitrogen, phosphorus, and potassium supplies. Weed Biol Manag 11:190-201 
Johnson WG, Ott EJ, Gibson KD, Nielsen RL, and Bauman TT (2007) Influence of nitrogen application timing on low density giant ragweed (Ambrosia trifida) interference in corn. Weed Technol 21:763-767

Johnson MG, Tingey DT, Phillips DL, and Storm MJ (2001) Review: Advancing fine root research with minirhizotrons. Environ Exp Bot 45:263-289.

Jordan NR, Zhang J, and Huerd S (2000) Arbuscular-mycorrhizal fungi: potential roles in weed management. Weed Res 40:397-410

Juroszek P, Drews S, Neuhoff D, and Kopke U (2004) Effects of organic fertilizers on the development of weeds and winter wheat. J Plant Dis Protect 19:611-618

Kirkland KJ and Beckie HJ (1998) Contribution of nitrogen fertilizer placement to weed management in spring wheat (Triticum aestivum). Weed Technol 12:507514

Kremer RJ and Li J (2003) Developing weed-suppressive soils through improved soil quality management. Soil Till Res 72:193-202

Liebman M and Gallandt ER (2002) Differential responses to red clover residue and ammonium nitrate by common bean and wild mustard. Weed Sci 50:521-529

Liebman M, Menalled FD, Buhler DD, Richard TL, Sundberg DN, Cambardella CA, and Kohler KA (2004) Impacts of composted swine manure on weed and corn nutrient uptake, growth, and seed production. Weed Sci 52:365-375

Lindsey AJ, Renner KA, and Everman WJ (2013) Cured dairy compost influence on weed competition and on 'Snowden' potato yield. Weed Technol 27:378-388

Little NG, Mohler CL, Ketterings QM, and DiTommaso A (2013) Effects of organic nutrient amendments on weed and crop growth. Manuscript under review, Weed Sci 
Luna-Orea P, Wagger MG, and Gumpertz ML (1996) Decomposition and nutrient release dynamics of two tropical legume cover crops. Agron J 88:758-764

Menalled FD, Liebman M, and Buhler DD (2004) Impact of composted swine manure and tillage on common waterhemp (Amaranthus rudis) competition with soybean. Weed Sci 52:605-613

Mesbah AO and Miller SD (1999) Fertilizer placement affects jointed goatgrass (Aegilops cylindrica) competition in winter wheat (Triticum aestivum). Weed Technol 13:374-377

Mohler CL, Dykeman C, Nelson EB, and DiTommaso A (2012) Reduction in weed seedling emergence by pathogens following the incorporation of green crop residue. Weed Res 52:467-477

Mt. Pleasant J and Schlather KJ (1994) Incidence of weed seed in cow (Bos sp.) manure and its importance as a weed source for cropland. Weed Technol 8:304-310

Odero DC and Wright AL (2013) Phosphorus application influences the critical period of weed control in lettuce. Weed Sci 61:410-414

Qasem JR and Hill TA (1995) Growth, development and nutrient accumulation in Senecio vulgaris L. and Chenopodium album L. Weed Res 35:187-196

Rasmussen PE (1995) Effects of fertilizer and stubble burning on downy brome competition in winter wheat. Commun Soil Sci Plan Anal 26:951-960

Rasmussen K (2002) Influence of liquid manure application method on weed control in spring cereals. Weed Res 42:287-298

Ruf-Pachta EK, Rule DM, and Dille JA (2013) Corn and palmer amaranth (Amaranthus palmeri) interactions with nitrogen in dryland and irrigated environments. Weed Sci 61:249-258 
Salas ML, Hickman MV, Huber DM, and Schreiber MM (1997) Influence of nitrate and ammonium nitrate on the growth of giant foxtail (Setaria faberi). Weed Sci 45:664-669

Santos BM, Dusky JA, Stall WM, Bewick TA, Shilling DG (2004a) Mechanisms of interference of smooth pigweed (Amaranthus hybridus) and common purslane (Portulaca oleracea) on lettuce as influenced by phosphorus fertility. Weed Sci 52:78-82

Santos BM, Dusky JA, Stall WM, and Gilreath JP (2004b) Influence of common lambsquarters (Chenopodium album) densities and phosphorus fertilization on lettuce. Crop Prot 23:173-176

Santos BM, Morales-Payan JP, Stall WM, and Bewick TA (1998) Influence of purple nutsedge (Cyperus rotundus) density and nitrogen rate on radish (Raphanus sativus) yield. Weed Sci 46:661-664

Sardi K and Beres I (1996) Effects of fertilizer salts on the germination of corn, winter wheat, and their common weed species. Commun Soil Sci Plant Anal 27:12271235

Shipley B and Keddy PA (1988) The relationship between relative growth rate and sensitivity to nutrient stress in twenty-eight species of emergent macrophytes. $\mathbf{J}$ Ecol 76:1101-1110

Shrefler JW, Shilling DG, Dusky JA, and Brecke BJ (1994) Influence of phosphorus fertility on intra- and interspecific interference between lettuce (Lactuca sativa) and spiny amaranth (Amaranthus spinosus). Weed Sci 42:574-578

Sobey DG (1981) Biological flora of the British Isles. Stellaria media (L) Vill. J Ecol 69:311-335

Stanley MR, Koide RT, and Shumway DL (1993) Mycorrhizal symbiosis increases growth, reproduction and recruitment of Abutilon theophrasti Medic. in the field. Oecologia 94:30-35 
Sweeney AE, Renner KA, Laboski C, and Davis A (2008) Effect of fertilizer nitrogen on weed emergence and growth. Weed Sci 56:714-721

Swink SN, Ketterings QM, Chase LE, and Czymmek KJ, and Mekken JC (2009) Past and future phosphorus balances for agricultural cropland in New York State. J Soil Water Conserv 64:120-133

Terry RM, Marquant PT, Camberato JJ, and Johnson WG (2012) The influence of nitrogen application timing and rate on volunteer corn interference in hybrid corn. Weed Sci 60:510-515

Teyker RH, Hoelzer HD, and Liebl RA (1991) Maize and pigweed response to nitrogen supply and form. Plant Soil 135:287-292

Thomson CJ, Marschner H, and Römheld V (1993) Effects of nitrogen fertilizer form on $\mathrm{pH}$ of the bulk soil and rhizosphere, and on the growth, phosphorus, and micronutrient uptake of bean. J Plant Nutr 16:493-506

Ugen MA, Wien HC, and Wortmann CS (2002) Dry bean competitiveness with annual weeds as affected by soil nutrient availability. Weed Sci 50:530-535

Vatovec C, Jordan N, Huerd S (2005) Responsiveness of certain agronomic weed species to arbuscular mycorrhizal fungi. Renew Agr Food Syst 20:181-189

Vengris K, Colby WG, and Drake M (1955) Plant nutrient competition between weeds and corn. Agron J 47:213-216

Weiner J (1990) Asymmetric competition in plant populations. TREE 5:360-364

Westerman PW, Bowers KE, Zering KD (2010) Phosphorus recovery from covered digester effluent with a continuous-flow struvite crystallizer. Appl Eng Agric 26:153-161

Wicks GA (1984) Integrated systems for control and management of downy brome (Bromus tectorum) in cropland. Weed Sci 32(Suppl 1):26-31 
Williams JT and Harper JL (1965) Seed polymorphism and germination. I. The influence of nitrates and low temperatures on the germination of Chenopodium album. Weed Res 5:141-150

Wulff RD and Bazzaz FA (1992) Effect of the parental nutrient regime on growth of the progeny in Abutilon theophrasti (Malvaceae). Am J Bot 79:1102-1107. 


\title{
CHAPTER 2:
}

\section{EFFECTS OF ORGANIC NUTRIENT AMENDMENTS ON WEED AND CROP GROWTH}

Neith G. Little, Charles L. Mohler, Quirine M. Ketterings, and Antonio DiTommaso*

* First, second, and fourth authors: Graduate Student, Senior Research Associate, and Associate Professor, Department of Crop and Soil Sciences, Cornell University, Ithaca, NY 14853. Third author: Associate Professor, Department of Animal Science, Cornell University, Ithaca, NY 14853. Corresponding author's E-mail: ng17@cornell.edu

\begin{abstract}
Sufficient fertility is important for crop growth and yield but supplying a balanced amount of $\mathrm{N}, \mathrm{P}$, and $\mathrm{K}$ with compost is a challenge and nutrient imbalances can benefit weeds more than crops. The goal of this study was to partition out the effects of the macronutrients $\mathrm{N}, \mathrm{P}$, and $\mathrm{K}$ from composted manure on the growth of corn, lettuce, and kale, and common weeds Powell amaranth, common lambsquarters, giant foxtail, and velvetleaf. Two field experiments were conducted over two years. Plants were grown in soil amended with composted poultry manure or single-nutrient organic $\mathrm{N}, \mathrm{P}$, and $\mathrm{K}$ fertility amendments. Single-nutrient $\mathrm{P}$ treatments with bone char did not adequately mimic P supply from composted manure. In both years, weeds responded more strongly than corn to the compost addition. Lettuce growth responded to compost, but due to the strong weed growth observed at high compost amendment rates, good weed control would be necessary to maintain this yield benefit. Powell
\end{abstract}


amaranth and common lambsquarters growth responses to compost were not due to $\mathrm{N}$ or K, and may have been driven by $\mathrm{P}$ or another nutrient. Velvetleaf growth response to compost appeared to be driven by $\mathrm{N}$. These results support fertility management based on soil testing and anticipated crop needs. Additionally, attention should be paid to nutrient ratios in compost amendments. Application rates that meet the crop's needs for one nutrient may oversupply other nutrients. Over-fertilization will not, by definition, benefit crop yield, but the results of this study show that high compost application rates are likely to increase weed growth.

\section{Nomenclature}

Common lambsquarters, Chenopodium album L. CHEAL; giant foxtail, Setaria faberi Herrm. SETFA; Powell amaranth, Amaranthus powellii S. Wats AMAPO; velvetleaf, Abutilon theophrasti Medik. ABUTH; corn, Zea mays L. 'VK7610'; lettuce, Lactuca sativa L. 'New Red Fire'; kale, Brassica oleracea L. 'Lacinato'.

\section{Key words}

Fertility management, nitrogen, phosphorus, potassium, poultry manure, compost, bone char, blood meal, potassium sulfate, weed growth 


\section{Introduction}

Sufficient fertility is important for crop growth and yield but increasing fertility applications can benefit weeds more than crops (Di Tomaso 1995). Many studies have reported that response of weeds and crops to fertility amendment varies among species. For example, in a greenhouse monoculture study, 19 weed species, including redroot pigweed (Amaranthus retroflexus L.), common lambsquarters, and green foxtail (Setaria viridis (L.) Beauv.), were more responsive to increasing phosphorus (P) than canola (Brassica napus L.). Common lambsquarters, green foxtail, and 15 other weed species were also more responsive to $\mathrm{P}$ than wheat (Triticum aestivum L.). In another greenhouse monoculture study with varying rates of $\mathrm{P}$ and $\mathrm{K}$, redroot pigweed was among the most responsive weeds studied, whereas corn biomass was much less affected by soil $\mathrm{P}$ or $\mathrm{K}$ concentration (Hoveland et al. 1976).

These varying responses to fertility can affect weed-crop competition. In a replacement series pot study, redroot pigweed became increasingly competitive against wheat with increasing nitrogen $(\mathrm{N})$ rates, but Persian darnel (Lolium persicum Boiss. \& Hohen ex. Boiss) and wild oat (Avena fatua L.) competitiveness were not affected by $\mathrm{N}$ (Blackshaw et al. 2008). In a field study corn yield increased with $\mathrm{P}$ fertilizer addition under weed-free conditions, but decreased with $\mathrm{P}$ addition when corn was grown in competition with redroot pigweed and common lambsquarters (Vengris et al. 1955). In another study, banded P fertilizer decreased the impact of common lambsquarters on lettuce yield compared with broadcast $\mathrm{P}$ application (Santos et al. 2004). 
Several studies have reported that organic fertility amendments — such as green manure, compost, and animal manure-decrease weed pressure relative to use of chemical fertilizers. Some have attributed decreased weed pressure in green manureamended soils to phytotoxic effects (Conklin et al. 2002; Davis and Liebman 2003), delayed N supply (Dyck et al. 1995), or promotion of microbial activity and thus increased seedbank mortality (de Cauwer et al. 2011; Mohler et al. 2012). Other studies report an increase in weed growth with organic fertility amendments. For example, a study by Liebman et al. (2004) reported an increase in weed growth with swine manure application where corn yield was not impacted. What characteristic of the manure caused this response was not tested.

Organic amendments can supply nutrients beyond crop needs because manure and compost contain all essential nutrients but often in ratios that do not correspond to crop needs. For example, when compost or manure is applied to meet the $\mathrm{N}$ needs of corn, $\mathrm{P}$ levels will build in the soil because the ratio of available $\mathrm{N}: \mathrm{P}$ in the amendment is lower than the ratio of N:P required by corn (Eghball and Power 1999). If compost is applied at rates to supply the crop's $\mathrm{N}$ requirement and the resulting oversupply of other nutrients benefits weed growth more than crop growth, reducing application rates while supplying part of the crop's $\mathrm{N}$ requirement with other sources (such as legume-based green manure) may contribute to reduced weed pressure. However, studies that evaluate the effect of nutrients from organic fertility amendments on weed growth are scarce.

The goal of this study was to partition out the effects of the macronutrients N, $\mathrm{P}$, and $\mathrm{K}$ from composted manure on the growth of several common weeds and crops. 
We hypothesized that when composted manure is applied in amounts sufficient to satisfy the $\mathrm{N}$ needs of crops, $\mathrm{P}$ and $\mathrm{K}$ supply in excess of crop needs will result in increased weed growth.

\section{Materials and Methods}

An incubation study was conducted to determine $\mathrm{N}$ release dynamics from blood meal compared to compost. Two field experiments were conducted, one in 2010 and one in 2011, to evaluate effects of different organic nutrient amendments on the growth of weeds and crops.

Soil incubation study. A soil incubation experiment was conducted to compare the timing of $\mathrm{N}$ availability from composted poultry manure and blood meal (the $\mathrm{N}$ treatment). Plowed but untreated soil was collected from a strip of soil neighboring the 2010 field experiment site on August 16. Soil was air-dried for $72 \mathrm{~h}$ at room temperature, and ground to pass a 2-mm sieve. The soil had a $\mathrm{pH}$ of 7.6, contained 3.3\% OM, 0 mg Morgan-extractable nitrate- $\mathrm{N} \mathrm{kg}^{-1}$ soil, $3 \mathrm{mg}$ Morgan-extractable $\mathrm{P}$ $\mathrm{kg}^{-1}$ soil, and $46 \mathrm{mg}$ Morgan-extractable $\mathrm{K} \mathrm{kg}^{-1}$ soil, classifying the soil as medium in $\mathrm{P}$ and K. Average water retention at $33 \mathrm{kPA}$ (field capacity) was $240 \mathrm{~g}_{\text {water }} \mathrm{kg}^{-1}$ soil. Samples were amended with one of three N sources: composted poultry manure (source, Kreher's Poultry Farm, Clarence, NY; $\mathrm{N}_{-} \mathrm{P}_{2} \mathrm{O}_{5}-\mathrm{K}_{2} \mathrm{O}$, 5-4-3), blood meal (Down to Earth Distributors, Inc., Eugene, OR; 12-0-0), or urea (Hewitt Brothers, Inc., Locke, NY; 46-0-0). The control was no fertility amendment. 
Samples were incubated in plastic containers $(475 \mathrm{~mL})$ with holes punched in the lids to maintain aerobic conditions while minimizing drying. One hundred grams of dry field soil were added to each container. The soil was brought to $75 \%$ field capacity. Samples were then incubated for two weeks to allow soil nitrate levels to stabilize prior to addition of the fertility amendments (Malhi and Nyborg 1979). Amendment rates were $0.01 \mathrm{~g} \mathrm{~N}$ per container. This equates to $486 \mathrm{~kg} \mathrm{~N} \mathrm{ha}^{-1}$. This rate is high but below the rate at which Petersen et al. (2004) observed delayed nitrification due to urea concentration. Urea was applied dissolved in deionized water. Compost was crushed in a mortar and pestle before application. Blood meal was applied in powdered form as purchased. Samples were randomly distributed within a dark growth chamber and incubated at $25 \mathrm{C}$. Throughout the incubation, soil moisture was maintained at $75-70 \%$ moisture capacity by weighing and rewetting samples at least twice each week. Four replicates were destructively sampled and analyzed for ammonia and nitrate at each sampling date. Samples were collected weekly for eight weeks. The last two sets of samples were collected 13 and 18 weeks after fertility amendment, to capture as much of the $\mathrm{N}$ release as possible. Samples were dried at 50 $\mathrm{C}$ and ground to pass a 2-mm sieve prior to analyses as described below (Fertility amendment and soil laboratory analyses).

2010 field experiment. This experiment was conducted at the Musgrave Research Farm, in Aurora, NY $\left(42.73^{\circ} \mathrm{N}, 76.65^{\circ} \mathrm{W}\right)$. The soil was a Lima silt loam (fine-loamy Oxyaquic Hapludalfs) with pH 7.7 and 3.7\% OM. The field site was in perennial ryegrass (Lolium perenne L.) with some volunteer red clover (Trifolium pratense L.) 
and white clover (Trifolium repens L.) for four years before the experiment. A composite soil sample (0-20 cm depth; 12 subsamples) was taken pre-treatment June 11. To homogenize the $\mathrm{N}$ input at plow-down, alfalfa hay was spread between the clover clumps such that hay and clover together supplied approximately $60 \mathrm{~kg} \mathrm{~N} \mathrm{ha}^{-1}$. Sod was mold-board plowed and disked June 18, and disked again June 21.

The crops corn and lettuce and the weeds Powell amaranth, common lambsquarters, and giant foxtail were grown in monoculture. Fertility treatments used four nutrient sources: (1) composted poultry manure (identical to the source used in the soil incubation study), (2) blood meal (identical to the source used in the soil incubation study), (3) bone char (North Country Organics, Bradford, VT, 16-0-0), and (4) potassium sulfate (North Country Organics, Bradford, VT, 0-0-50). The experiment was a partial factorial randomized block design. Treatments were designed around four exponentially increasing rates: $0 \mathrm{X}, 1 \mathrm{X}, 2 \mathrm{X}, 4 \mathrm{X}, 8 \mathrm{X}$, where $\mathrm{X}$ is the lowest $\mathrm{N}-\mathrm{P}_{2} \mathrm{O}_{5}-\mathrm{K}_{2} \mathrm{O}$ amendment rate of compost spanning the range of amounts a farmer might apply (Table 2.1). Other fertility sources evaluated the single effects of N, P, or $\mathrm{K}$ : four rates of blood meal matching the $\mathrm{N}$ in the compost; four rates of bone char matching the $\mathrm{P}$ in the compost, four rates of potassium sulfate matching the $\mathrm{K}$ in the compost; and four rates of a combination of blood meal, bone char, and potassium sulfate matching the $\mathrm{N}, \mathrm{P}$, and $\mathrm{K}$ in the compost (Table 2.1). Each rate by fertility treatment combination was replicated once in a randomized location in each of three spatial blocks. Two control plots in each block received no added fertility. 
Table 2.1: Macronutrients applied in each fertility treatment and amendment rate. Two controls $(0 \mathrm{X})$ with no fertility additions were included in each replication.

\begin{tabular}{cccccc}
\hline & \multicolumn{5}{c}{ Fertility treatment } \\
Rate & Compost $^{\mathrm{a}}$ & $\mathrm{N}^{\mathrm{b}}$ & $\mathrm{P}^{\mathrm{c}}$ & $\mathrm{K}^{\mathrm{d}}$ & "NPK"e \\
\cline { 2 - 6 } $1 \mathrm{X}$ & $45-35-22$ & $45-0-0$ & $0-35-0$ & $0-0-22$ & $45-35-22$ \\
$2 \mathrm{X}$ & $90-69-44$ & $90-0-0$ & $0-69-0$ & $0-0-44$ & $90-69-44$ \\
$4 \mathrm{X}$ & $180-139-89$ & $180-0-0$ & $0-139-0$ & $0-0-89$ & $180-139-89$ \\
$8 \mathrm{X}$ & $359-277-177$ & $359-0-0$ & $0-277-0$ & $0-0-177$ & $359-277-177$ \\
\hline
\end{tabular}

${ }^{\mathrm{a}}$ Composted poultry manure

${ }^{\mathrm{b}}$ Blood meal

${ }^{\mathrm{c}}$ Bone char

${ }^{\mathrm{d}}$ Potassium sulfate

${ }^{\mathrm{e}}$ Blood meal + bone char + potassium sulfate

Plants were grown in open-bottomed wooden boxes ( 46 by $46 \mathrm{~cm}$ ) dug $20 \mathrm{~cm}$ (plow depth) into the soil (Figure 2.1). Each box was filled with field soil mixed with fertilizer appropriate to the treatment. Common lambsquarters and giant foxtail seed dormancy were broken before planting by soaking seeds for $24 \mathrm{~h}$ in a $2 \%$ thiourea solution followed by air-drying under ambient room conditions (approx. 22 C) (Buhler and Hoffman 1999). All species were direct seeded into the soil in the boxes (Table 2.2). Seedlings that failed to emerge were replaced with transplants which were started July 13 (Table 2.2). The areas between boxes were cultivated August 6 to eliminate weeds. Remaining undesired weeds within or between the boxes were removed by hand. When weekly rainfall was less than $2.5 \mathrm{~cm}$ the experiment was irrigated by hand to ensure a total weekly water input of at least $2.5 \mathrm{~cm}$. 


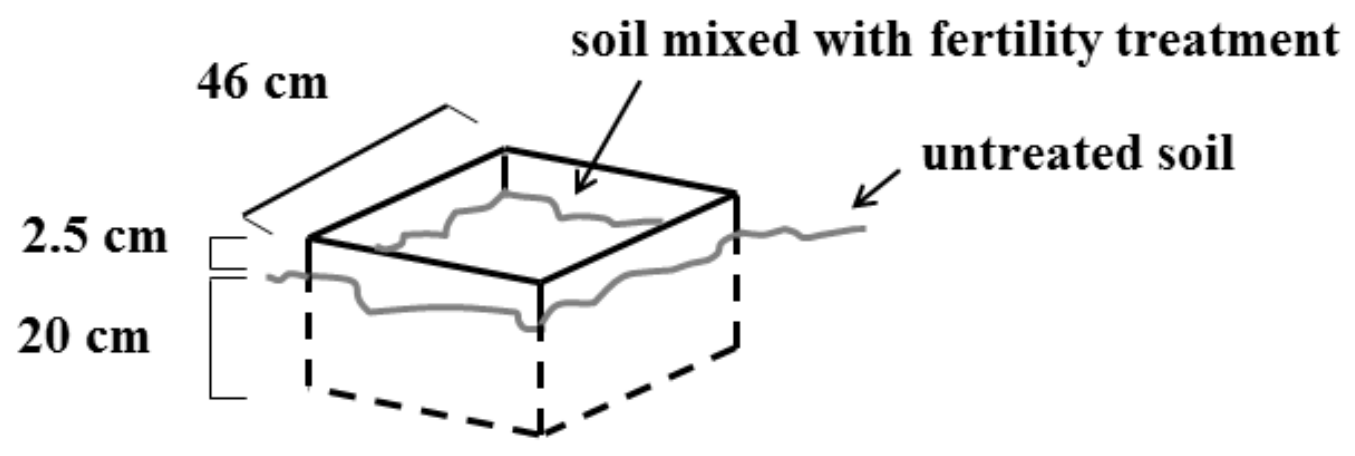

Figure 2.1: In the 2010 field experiment plants were grown in open-bottomed wooden boxes. Boxes were dug into the ground to plow depth and filled with soil mixed with a fertility treatment.

Crops were harvested when they reached marketable maturity: lettuce when it had formed heads and corn when ears were mature (Table 2.2). Weeds were harvested during seed set but before seeds were shed (Table 2.2). All above-ground biomass within the box was harvested, except for lettuce, where the lowest, dustiest leaves were discarded, consistent with grower practices. Biomass was dried at $40 \mathrm{C}$ until constant mass prior to determination of plot yield.

On November 2, soil samples were collected from the control, compost rate $8 \mathrm{X}$, and "NPK" rate $8 \mathrm{X}$ treatments. The N, P, and $\mathrm{K}$ alone treatments were not sampled because any effect of these treatments on soil nutrient levels should be observed in the "NPK" treatment. The $1 \mathrm{X}, 2 \mathrm{X}$, and $4 \mathrm{X}$ rates were not sampled because any effect on soil nutrient levels should be proportional to the effect observed in the $8 \mathrm{X}$ rate. Five soil cores $(0-20 \mathrm{~cm}$ depth) were collected from each box. Cores from different species but the same fertility treatment were pooled within each of the three replications. Soil samples were dried at 50 C and ground to pass a 2-mm sieve prior to soil fertility analyses. 
Table 2.2: Planting dates and days after planting (DAP) of field operations for the field experiments.

\begin{tabular}{|c|c|c|c|c|c|c|}
\hline \multicolumn{2}{|c|}{ Species } & Plant & Transplant & Thin & Thin to & Harvest \\
\hline \multirow{8}{*}{2010} & & & DAP & 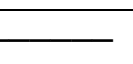 & plants $\mathrm{m}^{-2}$ & DAP \\
\hline & & & & & & \\
\hline & $\begin{array}{l}\text { Powell } \\
\text { amaranth }\end{array}$ & $\begin{array}{c}12-13 \\
\text { July }\end{array}$ & $12-16$ & $13-22$ & 29 & $72-75$ \\
\hline & Common & $12-13$ & $12-21$ & $13-22$ & 29 & $76-79$ \\
\hline & lambsquarters & July & & & & \\
\hline & Giant foxtail & $12-13$ & 12 & $17-22$ & 29 & $69-70$ \\
\hline & Corn & $\begin{array}{c}\text { July } \\
\text { 12-13 } \\
\text { July }\end{array}$ & None & 6 & 14 & $70-74$ \\
\hline & Lettuce & 20 July & 14 & 14 & 14 & 73 \\
\hline \multicolumn{7}{|l|}{2011} \\
\hline & $\begin{array}{l}\text { Powell } \\
\text { amaranth }\end{array}$ & 10 June & 12 & $27-54$ & 7 & $93-98$ \\
\hline & Common & 13 June & $9-12$ & $43-49$ & 7 & $100-$ \\
\hline & lambsquarters & & & & & 101 \\
\hline & Giant foxtail & 10 June & 12 & $17-59$ & 7 & $105-$ \\
\hline & & & & & & 117 \\
\hline & Velvetleaf & 13 June & $10-14$ & $36-49$ & 7 & $79-87$ \\
\hline & $\begin{array}{l}\text { Corn } \\
\text { (Reps } 1 \text { and 2) }\end{array}$ & 10 June & $12-14$ & $14-26$ & 7 & $\begin{array}{l}110- \\
116\end{array}$ \\
\hline & Corn $(\operatorname{Rep} 3)^{*}$ & 6 July & None & $20-21$ & 7 & 91 \\
\hline & Lettuce & 10 June & 12 & $33-52$ & 7 & $61-63$ \\
\hline & Kale & 13 June & $9-51$ & $51-64$ & 5 & 114 \\
\hline
\end{tabular}

* After the initial corn planting on June 10, crows destroyed replicates 3 and 4. On 6 July the surviving plants in replicate 3 were transplanted to replicate 4 and replicate 3 was entirely replanted. Replicate 4 was later deemed unusable. 
2011 field experiment. This experiment was conducted at the Mount Pleasant Research Farm, Ithaca, NY $\left(42.46^{\circ} \mathrm{N}, 76.37^{\circ} \mathrm{W}\right)$. The soil was a Mardin channery silt loam (coarse-loamy Typic Fragiudepts) with pH 5.3 and 4.1\% OM. For two years before the experiment the site was a fallow field dominated by quackgrass (Elytrigia repens (L.) Desv. ex Nevski) and goldenrod (Solidago spp.). The field was sprayed May 25 with glyphosate (Honcho Plus, Monsanto, St. Louis, MO) at a rate of $1 \mathrm{~kg}$ ai $\mathrm{ha}^{-1}$. On the same day, wet coarse lime with an effective neutralizing value (ENV) of $66 \%$ was applied at the rate of 9,000 $\mathrm{kg} \mathrm{ha}^{-1}$ (Hanson's Quarry, Watertown, NY) to increase the soil $\mathrm{pH}$ to 6.0. The field was plowed and then disked May 27 and disked again May 31. A pre-treatment soil sample (12 subsamples, $0-20 \mathrm{~cm}$ depth) was taken on June 1. The experiment was not irrigated, except when seedlings were transplanted to fill gaps in emergence. From seeding to harvest, average weekly rainfall was 2.7 $\mathrm{cm}$. In addition to the five species evaluated in the 2010 experiment, kale and velvetleaf were grown.

The focus of the 2011 experiment was the effects of $\mathrm{N}$ and $\mathrm{P}$. The field site soil P concentration $\left(3.6 \mathrm{~kg} \mathrm{ha}^{-1}\right)$ was low for corn and lettuce production (Cornell Cooperative Extension 2011a, 2011b), which allowed us to experimentally vary the $\mathrm{P}$ supply. In the 2010 experiment, despite medium soil K levels for corn and lettuce production (Cornell Cooperative Extension 2011a, 2011b), none of the species responded to the potassium sulfate treatment (see Results and Discussion). The $\mathrm{K}$ treatment was removed from the 2011 design because a site high in soil test $\mathrm{K}$ was selected (Cornell Cooperative Extension 2011a, 2011b) and a response to K was unlikely. 
The experiment had a partial factorial, randomized, blocked design. Each fertility treatment and two control treatments with no fertility additions occurred in each of four replications. Treatments were designed to compare crop and weed responses to (1) $\mathrm{N}$ vs. compost, given adequate $\mathrm{P}$ and (2) $\mathrm{P}$ vs. compost, given adequate N. Treatments included: (1) four rates of compost or four rates of blood meal, all applied to plots that had received enough bone char to meet the recommended rate of $\mathrm{P}$, and (2) four rates of compost or four rates of bone char, all applied to plots that had received enough blood meal to supply the recommended rate of $\mathrm{N}$ (Table 2.3). Two control plots that received no fertility additions were included in each replication. Recommended $\mathrm{N}$ and $\mathrm{P}$ rates were calculated from Cornell Cooperative Extension guidelines for field corn and lettuce (Cornell Cooperative Extension 2011a, 2011b). 
Table 2.3: Treatments in 2011 field experiment. One set of treatments ("Recommended N") compared the effect of compost versus P (as bone char) at various rates when sufficient $\mathrm{N}$ (as blood meal) was supplied, and another ("Recommended P") compared the effect of compost versus $\mathrm{N}$ (as blood meal) at various rates when sufficient $\mathrm{P}$ (as bone char) was supplied.

\begin{tabular}{|c|c|c|}
\hline \multicolumn{3}{|c|}{ Recommended N } \\
\hline Fertility treatment & Rate & Nutrients applied \\
\hline \multicolumn{3}{|r|}{$\mathrm{kg} \mathrm{ha}{ }^{-1} \mathrm{~N}-\mathrm{P}^{2} \mathrm{O}^{5}-\mathrm{K}^{2} \mathrm{O}$} \\
\hline Control & $0 \mathrm{X}$ & $180-0-0$ \\
\hline Compost & $1 \mathrm{X}$ & $225-35-22$ \\
\hline \multirow{7}{*}{ Bone char } & $2 \mathrm{X}$ & $270-69-44$ \\
\hline & $4 X$ & $360-139-89$ \\
\hline & $8 \mathrm{X}$ & $539-277-177$ \\
\hline & $1 \mathrm{X}$ & $180-35-0$ \\
\hline & $2 \mathrm{X}$ & $180-69-0$ \\
\hline & $4 X$ & $180-139-0$ \\
\hline & $8 \mathrm{X}$ & $180-277-0$ \\
\hline \multicolumn{3}{|c|}{ Recommended P } \\
\hline Fertility treatment & Rate & Nutrients applied \\
\hline & & $\mathrm{kg} \mathrm{ha}^{-1} \mathrm{~N}-\mathrm{P}^{2} \mathrm{O}^{5}-\mathrm{K}^{2} \mathrm{O}$ \\
\hline Control & $0 \mathrm{X}$ & $0-139-0$ \\
\hline \multirow[t]{4}{*}{ Compost } & $1 \mathrm{X}$ & $45-174-22$ \\
\hline & $2 \mathrm{X}$ & $90-208-44$ \\
\hline & $4 X$ & $180-278-89$ \\
\hline & $8 \mathrm{X}$ & $359-416-177$ \\
\hline \multirow[t]{4}{*}{ Blood meal } & $1 \mathrm{X}$ & $45-139-0$ \\
\hline & $2 \mathrm{X}$ & $90-139-0$ \\
\hline & $4 X$ & $180-139-0$ \\
\hline & $8 \mathrm{X}$ & $359-139-0$ \\
\hline
\end{tabular}


Because preparing the in-ground boxes in 2010 caused an undesirable delay in planting, in 2011 a different set-up was used. One row of each species was planted across plots of soil into which fertility treatments had been disked on June 7 (Figure 2.2). The position of the species was randomized within each replication. The rows of experimental species (corn, Powell amaranth, etc.) were separated by buffer rows of sorghum-sudangrass (Sorghum bicolor (L.) Moench. ssp. bicolor X S. bicolor (L.) Moench. ssp. drummondii (Nees ex Steud.) de Wet \& Harlan) 'Black Hawk 12' so that neighbor competition would be the same for all species. One row of each of the seven experimental species alternating with rows of sorghum-sudangrass, resulted in thirteen rows in each plot (Figure 2.2). Rows were spaced $76 \mathrm{~cm}$ apart. The buffer rows of sorghum-sudangrass were cut back to a height of $46 \mathrm{~cm}$ on August 8 and September 9 to minimize competition for light with experimental plants.

All species were direct seeded (Table 2.2). Slightly different dormancybreaking methods were used from the 2010 experiment due to results from a pilot study (data not shown) to determine the method most effective on the available seeds. Powell amaranth and giant foxtail seed dormancy were broken before planting by soaking seeds for $24 \mathrm{~h}$ in a $2 \%$ thiourea solution followed by air drying under ambient room conditions (approx. $22 \mathrm{C}$ ). Common lambsquarters seed dormancy was broken by soaking for $15 \mathrm{~min}$ in concentrated $(95-98 \%) \mathrm{H}_{2} \mathrm{SO}_{4}$ followed by washing and airdrying before planting (Buhler and Hoffman 1999). Seedlings that failed to emerge 


\section{4 blocked replications}

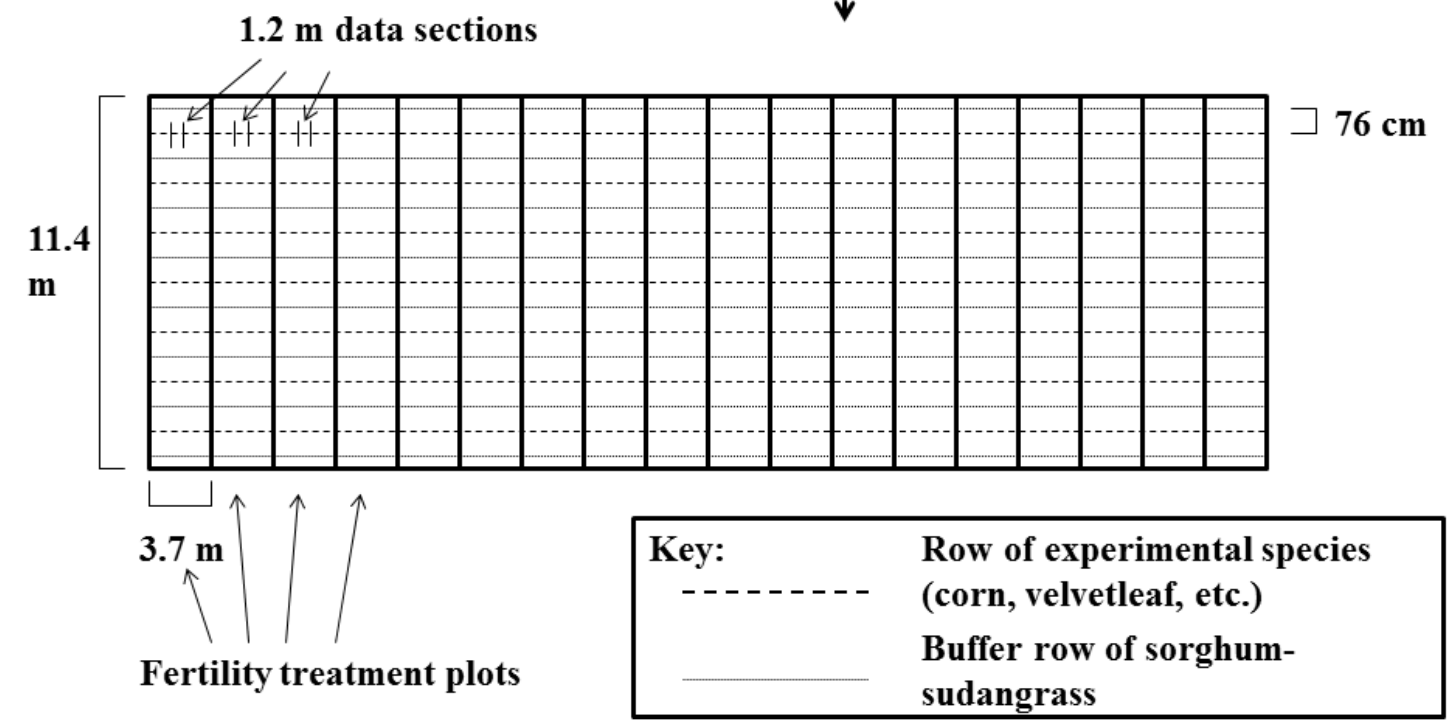

Figure 2.2: Layout of 2011 field experiment. In each of four blocked replications, experimental species were planted in rows across fertility treatment plots. Data were collected only from the center $1.2 \mathrm{~m}$ of each plot, to prevent roots from extending into neighboring treatments. Sorghum-sudangrass was grown in between rows of experimental species, to ensure all species experienced the same neighbor effects.

were replaced with transplants dug from the same treatment in another replication, where seedlings had to be thinned anyway (Table 2.2). Due to poor stand establishment, probably because of cabbage flea-beetle (Phylotreta cruciferae Goeze) damage, some kale seedlings from the buffer sections were transplanted into the center data sections. Undesired weeds between rows were cultivated on July 1. Remaining undesired weeds within and between the rows were removed by hand. 
Due to crow (Corvus brachyrhynchos Brehm) damage to replications 3 and 4 of corn, on June 6 the surviving seedlings in replication 3 were transplanted into the holes left by the crows in replication 4 , and replication 3 was replanted completely. Corn re-established quickly in replication 3 but the transplanted corn seedlings in replication 4 did not grow well, so replication 4 of corn was excluded from analysis. No other species were damaged by crows. To control cabbage flea-beetles, kale was sprayed with spinosad (Entrust, Dow AgroSciences, Indianapolis, IN) at $100 \mathrm{~g}$ ai ha ${ }^{-1}$ and kaolin (Surround, NovaSource, Phoenix, AZ) at $34 \mathrm{~kg}$ ai ha ${ }^{-1}$ on June 30, and with spinosad alone on July 8 and August 5. On the latter two dates, common lambsquarters was also sprayed with spinosad to control cabbage webworms (Hellula undalis Fabricius).

To limit sampling of plants with roots outside of the treated soil volume, data were collected only from the center $1.2 \mathrm{~m}$ of row within each $3.6 \mathrm{~m}$ wide plot. This left as a buffer $1.2 \mathrm{~m}$ of row on either side within each plot (Fig. 2). The data section of each plot contained 6 plants for all species except kale (4 plants) and lettuce (5 plants), due to their larger in-row spacing. Above-ground biomass was harvested and dried as in 2010 (Table 2.2). Kale was considered to have reached market maturity when growth had slowed due to cold weather.

On October 30, soil samples were collected from control, base $\mathrm{N}+$ compost rate $8 \mathrm{X}$, and base $\mathrm{N}+\mathrm{P}$ rate $8 \mathrm{X}$ plots in each of the four replications. Five soil cores $(0-20 \mathrm{~cm}$ depth) were collected from the center data section of each plot and combined. Soil samples were analyzed for plant available nutrients using the Morgan's analysis (Morgan 1941). 
Fertility amendment and soil laboratory analyses. Fertility amendments were analyzed at Brookside Laboratories, Inc. (New Breman, $\mathrm{OH}$ ). Total $\mathrm{N}$ was measured by dry combustion with a Vario Max CN analyzer (Elementar, Mt. Laurel, NJ). Available $\mathrm{P}$ was extracted with ammonium citrate and available $\mathrm{K}$ was extracted with nitric acid microwave digestion (AOAC 1995). After extraction, available $\mathrm{P}$ and $\mathrm{K}$ were analyzed using a 6500 duo ICP (ThermoFisher Scientific, Waltham, MA).

Soils were analyzed at the Cornell Nutrient Analysis Laboratory (Ithaca, NY) using methods described in Wolf and Beegle (1995). For the incubation study, soils were analyzed for potassium chloride extractable nitrate and nitrite, and ammonium (Keeney and Nelson 1982) and analyzed using a continuous flow digital colorimetric analyzer (Auto-Analyzer 3, Bran-Luebbe, Norderstedt, Germany). Soil organic N supply was measured using the Illinois Soil Nitrogen Test (ISNT) according to Khan et al. (2001) with the enclosed griddle modification (Klapwyk and Ketterings 2005). Soil nitrate-N, P, and K were extracted using the Morgan method (Morgan 1941). Samples were shaken in a 1:5 soil:solution (v:v) ratio for $15 \mathrm{~min}$ and filtered through Whatman No. 2 filter paper. Morgan-extractable Nitrate-N and P were measured colorimetrically (Murphy and Riley 1962) using a continuous flow digital colorimetric analyzer (Auto-Analyzer 3, Bran-Luebbe, Norderstedt, Germany). K was measured using an inductively coupled plasma-atomic emission spectrometer (Spectro-CIROS, Spectro Analytical Instruments, Inc., Mahwah, NJ). Organic matter was measured by loss on ignition at a temperature of $500 \mathrm{C}$. Soil $\mathrm{pH}$ was measured in water (w: $\mathrm{v}$ ratio of 1:1). Soil water retention at $33 \mathrm{kPA}$ (field capacity) was measured using a pressure plate extractor (Soilmoisture Equipment Corp., Santa Barbara, CA). 
Data analysis. Analyses were conducted using the software JMP and SAS (JMP Pro, Version 10.; SAS Version 9.2; SAS Institute Inc., Cary, NC, USA).

Aboveground plant biomass: Exploratory ANOVAs tested for curvilinearity of the responses to nutrient rates in the field experiments. The 2010 biomass data were transformed to natural logarithms to homogenize variance prior to ANOVA, but this was unnecessary for the 2011 data. In subsequent non-linear analysis of the 2010 data, both the biomass data and the fitted models were transformed with natural logarithms. This transformation of both sides of the equation scales the parameters to the untransformed data. In the exploratory ANOVAs, the threshold for further non-linear analysis was a quadratic term with significance of $P<0.10$. A liberal standard for rejecting the null hypothesis of linearity was appropriate in this case because biological principles indicate that any productivity response to nutrient rate should be curvilinear. When the threshold was not met, the ANOVA was run again with the second order effects removed to test for significance $(P<0.05)$ of the linear effects of fertilizer rate and interactions with fertilizer type. In the exploratory ANOVA of the velvetleaf 2011 biomass data, both curvilinearity and a significant $(P<0.05)$ replicate effect were detected, so before non-linear analysis the velvetleaf data were transformed to remove the replicate effect by subtracting the block mean and adding the grand mean to each value.

In non-linear analysis, an F-test was used to compare the fit of a common model for two nutrient sources to a model allowing separate fitted curves for biomass from the two fertility treatments. For the common model: 


$$
Y=a-g e^{-h R}
$$

where $Y$ is biomass, $a$ is a fitted parameter representing the maximum biomass, $g$ is a fitted parameter representing the yield loss relative to the maximum potential yield when no fertility is added above what is already present in the soil, $h$ is a fitted parameter representing the rate of increase in biomass with increasing nutrient amendment, and $R$ is the rate of the fertility treatment $(0,1,2,4,8)$. The model giving separate curves for the two nutrient sources has the form

$$
Y=F_{C}\left(a_{C}-g_{C} e^{-h_{C} R_{C}}\right)+F_{N}\left(a_{N}-g_{N} e^{-h_{N} R_{N}}\right)
$$

where $F_{C}$ and $F_{N}$ are dummy variables coded 0 for absence or 1 for presence of the fertility treatment compost or another nutrient treatment, respectively, specifically, "NPK" in 2010, and $\mathrm{N}$ as blood meal in 2011. Other parameters $(a, g, h$, ) are as in Eq. 1 and vary with fertility treatment. The Mitscherlich equation is commonly used to model yield response to fertility (Gardner et al. 1985), but these non-linear models closely approximate the form of the Mitscherlich equation (Figure 2.3) and are substantially more likely to produce convergence during non-linear regression. Significant difference between the two models was determined by an F-test $(P<0.05)$ on the difference between the residual sum of squares (Gomez and Gomez 1984). The pooled variance among replicates at each rate was used as the denominator of the Fratio rather than the usual sum of squared error from the regression, because the former provides an estimate of error that is independent of the particular model (Mohler and Galford 1997). 


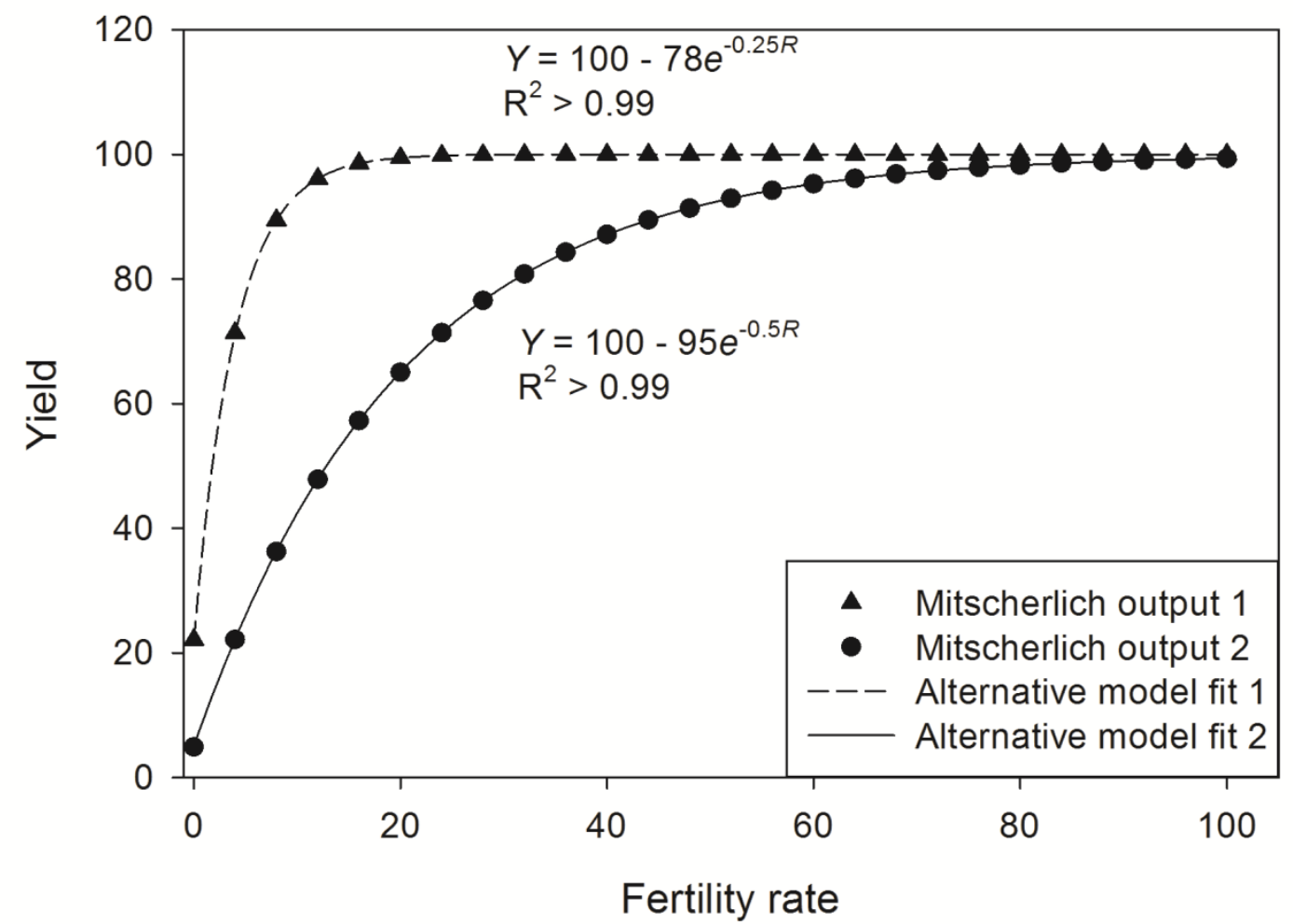

Figure 2.3: Examples of two Equation 1 models fitted to points generated with the Mitscherlich equation $\left(Y=a\left(1-e^{-c(b+R)}\right)\right.$. Equation 1 models were fitted to a series of Mitscherlich equation outputs generated using all possible combinations of the parameters $a=100,500,1000 ; b=1,5,10 ; c=0.1,0.25,0.9$ gave a mean approximate $\mathrm{R}^{2}>0.999$.

Soil samples: Effect of fertility amendment on soil nutrients was analyzed using the Fit Model procedure in JMP. Means were separated at $P<0.05$ by Least Significant Difference (LSD).

Soil incubation: Means of the three $\mathrm{N}$ fractions for the untreated controls were calculated for each sampling date to estimate the baseline $\mathrm{N}$ levels in un-amended soil. These control means were then subtracted from the $\mathrm{N}$ measurements in the three $\mathrm{N}$ source treatments (urea, composted manure, and blood meal) before statistical analysis. To test whether $\mathrm{N}$ supply from different $\mathrm{N}$ sources varied over time, an 
ANOVA was run using the Fit Model procedure in JMP, with sampling date, Nsource, and their interaction as fixed effects. The effects of $\mathrm{N}$-source were compared $a$ posteriori by separating their least-square means at $P<0.05$ by LSD.

\section{Results and Discussion}

Soil incubation. The ISNT-measured $\mathrm{N}$ did not significantly differ among blood meal and composted poultry manure $(\mathrm{F}=0.87, P>0.05$, data not shown) indicating that the organic soil $\mathrm{N}$ supply and $\mathrm{NH}_{4}-\mathrm{N}$ levels were not affected differently by the three amendments. There was no interaction between amendment type and sampling date for either $\mathrm{NH}_{4}-\mathrm{N}$ and $\mathrm{NO}_{3}-\mathrm{N}$ (Figure 2.4; $\mathrm{F}=1.69, \mathrm{P}>0.05$ and $\mathrm{F}=0.79, \mathrm{P}>0.05$, respectively). These results indicate that although $\mathrm{N}$-availability varied over time, the difference in $\mathrm{N}$-availability among the $\mathrm{N}$-sources did not vary significantly over time. Although, $\left(\mathrm{NO}_{3}+\mathrm{NO}_{2}\right)-\mathrm{N}$ supply from blood meal was $18 \%$ higher than $\left(\mathrm{NO}_{3}+\mathrm{NO}_{2}\right)-\mathrm{N}$ supply from compost, when averaged across sampling dates, A posteriori tests found no significant difference in $\mathrm{N}$-supply from blood meal and compost. Over the 18 week incubation, supply of $\mathrm{N}$ from blood meal was thus as great as or greater than $\mathrm{N}$ supply from compost indicating that blood meal can be used as a proxy for $\mathrm{N}$ release from compost. 


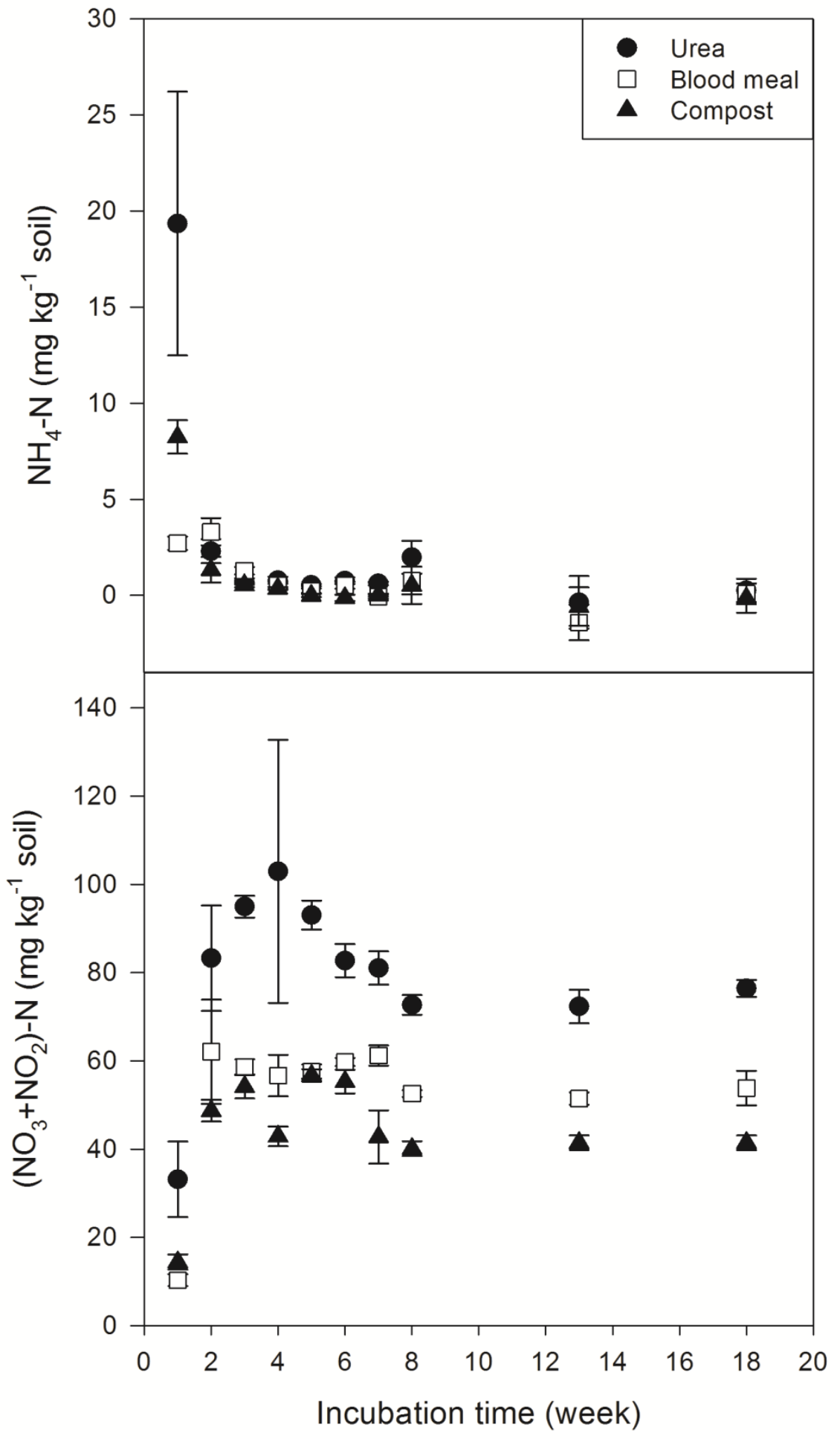

Figure 2.4: Nitrogen release and nitrification over time in soil amended with compost, blood meal, or urea. Bars represent standard error of the mean. 
Effects of fertility treatments on soil nutrient levels. In 2010, bone char amendment in the "NPK" treatment had no significant effect on soil P levels relative to the untreated control, whereas compost amendment significantly raised soil P levels (Table 2.4). This difference may be explained by a recent study which reports that at high soil pH, P in bone char may not solubilize (Warren et al. 2009). The calcareous soil at the 2010 field site had pH 7.7. In 2011, despite relocating to a field site with lower $\mathrm{pH}$, bone char amendment again had no effect on soil P levels (Table 2.4). This may have been due to the spring application of lime to raise soil $\mathrm{pH}$ to approximately 6.0, below which the crops would have grown poorly (Cornell Cooperative Extension 2011a, 2011b). Calcium in the lime may have bound any P solubilized from the bone char. Alternatively, the $\mathrm{P}$ in the bone char may solubilize much more slowly than the $\mathrm{P}$ in the composted poultry manure, resulting in no effect on soil $\mathrm{P}$ within a single growing season.

In both years, the $\mathrm{P}$ treatments did not mimic $\mathrm{P}$ supply from composted poultry manure well enough to test the hypothesis that weed response to compost is driven by P. Thus our discussion of results will focus on the other treatments (compost vs. $\mathrm{N}$ and $\mathrm{K}$ in 2010, compost vs. $\mathrm{N}$ in 2011). The 2010 "NPK" treatment will be referred to below as " $\mathrm{N}+\mathrm{K}$ " because no significant $\mathrm{P}$ was supplied. The 2010 results for $\mathrm{N}$ or $\mathrm{K}$ alone were not different from " $\mathrm{N}+\mathrm{K}$ " for any species and, for brevity, are not shown. In 2010, potassium sulfate amendment resulted in soil K levels intermediate between control and compost treatments, but not significantly different from either (Table 2.4). Potassium sulfate is a well-established $\mathrm{K}$ fertilizer that is readily dissolved 
in the soil solution (Greenwood et al. 1980), making it a reasonable surrogate for the K in composted poultry manure for the purposes of these experiments.

Table 2.4: Mean $\mathrm{pH}$, organic matter, and Morgan extractable $\mathrm{P}$ and $\mathrm{K}$ results for soil samples from the 2010 and 2011 field experiments. All samples other than the pretreatment samples were taken after harvest. Values in parentheses are standard errors. Within years, means that share the same letter are not significantly different. See table 1 for fertility treatment application rates.

\begin{tabular}{|c|c|c|c|c|c|}
\hline Treatment & $\begin{array}{l}\text { No. } \\
\text { samples }\end{array}$ & $\mathrm{pH}$ & $\mathrm{OM}$ & $\mathrm{P}$ & $\mathrm{K}$ \\
\hline \multirow{2}{*}{\multicolumn{6}{|c|}{$-\mathrm{kg} \mathrm{ha}^{-1}$}} \\
\hline & & & & & \\
\hline Pre-treatment & 1 & 7.70 & 3.7 & 7.8 & 140 \\
\hline Control & 3 & $7.69(0.06) \mathrm{a}$ & $\begin{array}{l}3.1(0.2) \\
\mathrm{a}\end{array}$ & $5.2(0.5) b$ & $140(18) b$ \\
\hline Compost, 8X & 3 & $7.66(0.07) \mathrm{a}$ & $\begin{array}{l}3.1(0.1) \\
\mathrm{a}\end{array}$ & $17.8(2.7) \mathrm{a}$ & $200(5) \mathrm{a}$ \\
\hline NPK, $8 \mathrm{X}$ & 3 & $7.60(0.08) \mathrm{a}$ & $\begin{array}{l}3.2(0.2) \\
\mathrm{a}\end{array}$ & $6.3(0.5) b$ & $180(17) a b$ \\
\hline \multicolumn{6}{|l|}{2011} \\
\hline Pre-treatment & 1 & 6.05 & 4.2 & 5.1 & 190 \\
\hline $\mathrm{N}+0 \mathrm{X}$ & 4 & $5.53(0.26) \mathrm{a}$ & $\begin{array}{l}3.9(0.1) \\
\mathrm{a}\end{array}$ & $4.2(0.8) b$ & $200(26) a b$ \\
\hline $\begin{array}{l}\mathrm{N}+\text { compost, } \\
\quad 8 \mathrm{X}\end{array}$ & 4 & $5.88(0.11) \mathrm{a}$ & $\begin{array}{l}3.8(0.1) \\
\mathrm{a}\end{array}$ & $14.6(0.8) \mathrm{a}$ & $230(22) a$ \\
\hline $\begin{array}{l}\mathrm{N}+\text { bone } \\
\text { char, } 8 \mathrm{X}\end{array}$ & 4 & $5.73(0.13) \mathrm{a}$ & $\begin{array}{l}3.7(0.1) \\
\mathrm{a}\end{array}$ & $4.5(0.5) b$ & $160(18) b$ \\
\hline
\end{tabular}

Effects of treatments on biomass. In 2010, biomass of species in the $\mathrm{N}$ or $\mathrm{K}$ alone treatments was not different from biomass of species in the " $\mathrm{N}+\mathrm{K}$ " treatments and, for brevity, data from the $\mathrm{N}$ or $\mathrm{K}$ alone treatments are not shown. Increasing $\mathrm{K}$ did not increase the growth of any of the five species grown in 2010 (Figures 2.5 and 2.6). 
Response to K was not tested by treatments in 2011. We conclude based on the 2010 results that crop and weed response was not limited by $\mathrm{K}$ addition and that $\mathrm{K}$ was not the driver of crop and weed response to compost.

Weed responses to compost were more substantial in 2010 than in 2011 (Figure 2.5). Growth of most weeds increased with compost rate, but not with blood meal (N) alone. In both 2010 and 2011, Powell amaranth and common lambsquarters growth was significantly more responsive to increasing compost amendment than to increasing blood meal amendment (Figure 2.5, Tables 2.5 and 2.6). Giant foxtail response to increasing compost was more variable across years than the other weeds studied. In 2010, giant foxtail growth was significantly more responsive to increasing compost amendment than to increasing blood meal amendment (Figure 2.5, Table 2.6). In 2011, giant foxtail growth in compost and blood meal treatments was not significantly different (Figure 2.5, Table 2.5). However, the slope of the regression of biomass on compost rate was substantial (Figure 2.5), and the lack of significance may have been due to exceptionally large variation among replications. Velvetleaf (grown only in 2011) responded similarly to compost and blood meal, with growth increasing significantly with increasing rate of either amendment (Figure 2.5, Table 2.6). 

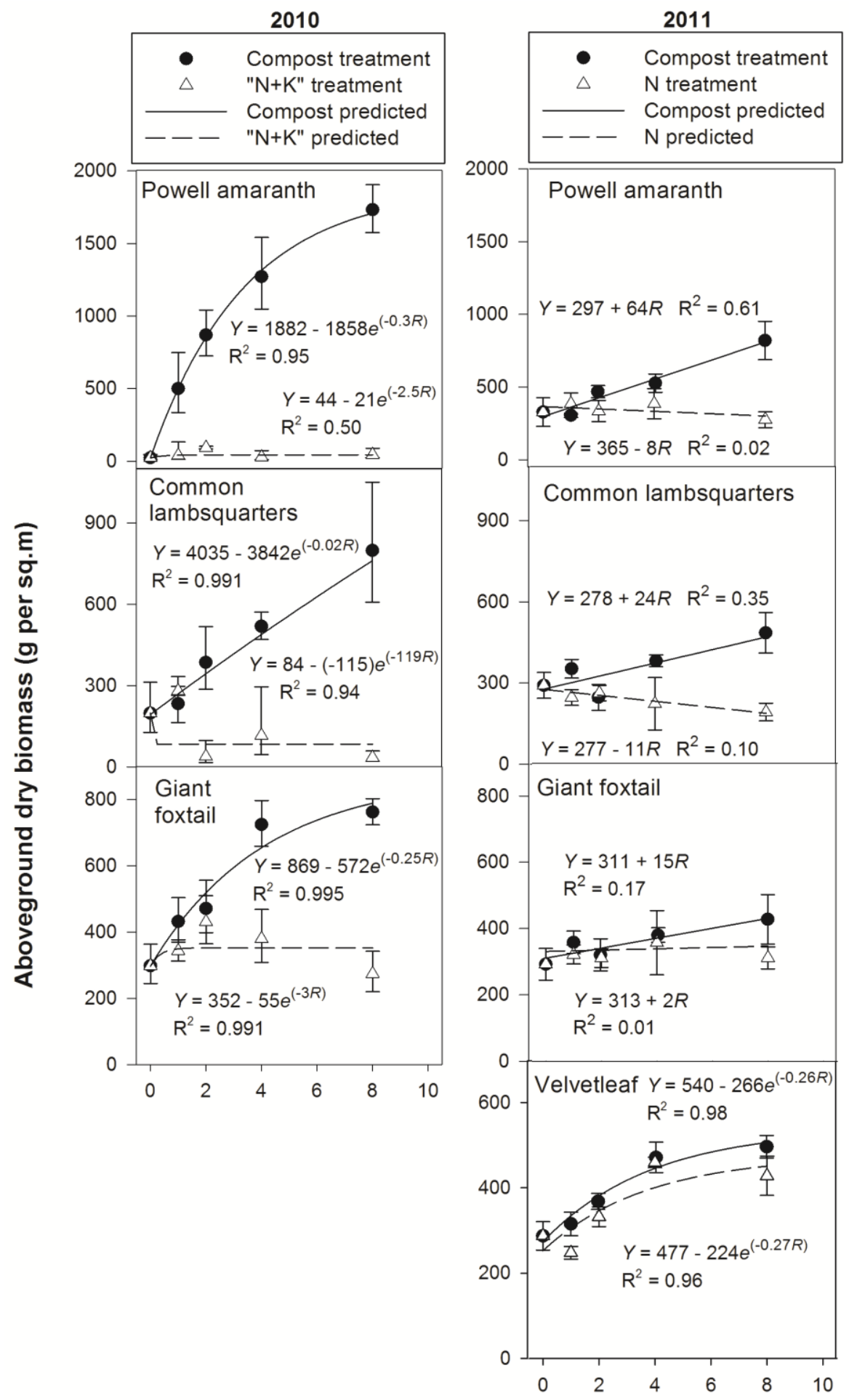

Fertility treatment rate

Figure 2.5: Weed growth across increasing amendment with composted poultry manure or blood meal $(\mathrm{N})$. Linear growth responses were modeled by ANOVA. Nonlinear growth responses were modeled with an alternative to the Mitscherlich equation. Bars represent standard error of the mean. 
Table 2.5: Significance of analysis of variance for aboveground biomass of the crops and weeds which exhibited linear responses to increasing fertility rate. No 2010 biomass data exhibited linear responses.

\begin{tabular}{lccccc}
\hline \multirow{2}{*}{ Effect } & df & \multicolumn{4}{c}{ Species (all 2011) } \\
\cline { 2 - 6 } & & Corn & $\begin{array}{c}\text { Powell } \\
\text { amaranth }\end{array}$ & $\begin{array}{c}\text { Common } \\
\text { lambsquarters }\end{array}$ & Giant foxtail \\
\hline Amendment & 1 & NS & $* * *$ & $* *$ & NS \\
Rate & 1 & NS & $* * *$ & NS & $*$ \\
Amendment $\times$ rate & 1 & NS & $* * *$ & $*$ & NS \\
\hline NS, not significant; & (,$P \leq 0.05 ; * *$, Significant at $P \leq 0.01 ; * * *$, Significant at $P \leq$ \\
0.001 & & &
\end{tabular}

Table 2.6: F-test comparison of the difference between the residual sum of squares of Equations 1 and 2 as models for aboveground biomass. If the difference was significant, the effect of increasing rates of the fertility treatments (compost or " $\mathrm{N}+\mathrm{K}$ " in 2010; compost or $\mathrm{N}$ in 2011) on biomass was concluded to be different.

\begin{tabular}{lc}
\hline Species & $\begin{array}{c}\text { Difference between Eq. 1 } \\
\text { and Eq. 2 }\end{array}$ \\
\hline 2010 & $* * *$ \\
Powell amaranth & $* * *$ \\
Common lambsquarters & $* *$ \\
Giant foxtail & $*$ \\
Corn & $*$ \\
Lettuce & \\
2011 & $\mathrm{NS}$ \\
Kale & $\mathrm{NS}$ \\
Velvetleaf & $\mathrm{NS}$ \\
Lettuce & \\
\hline$* P \leq 0.05, * * P \leq 0.01, * * * P \leq 0.001$
\end{tabular}



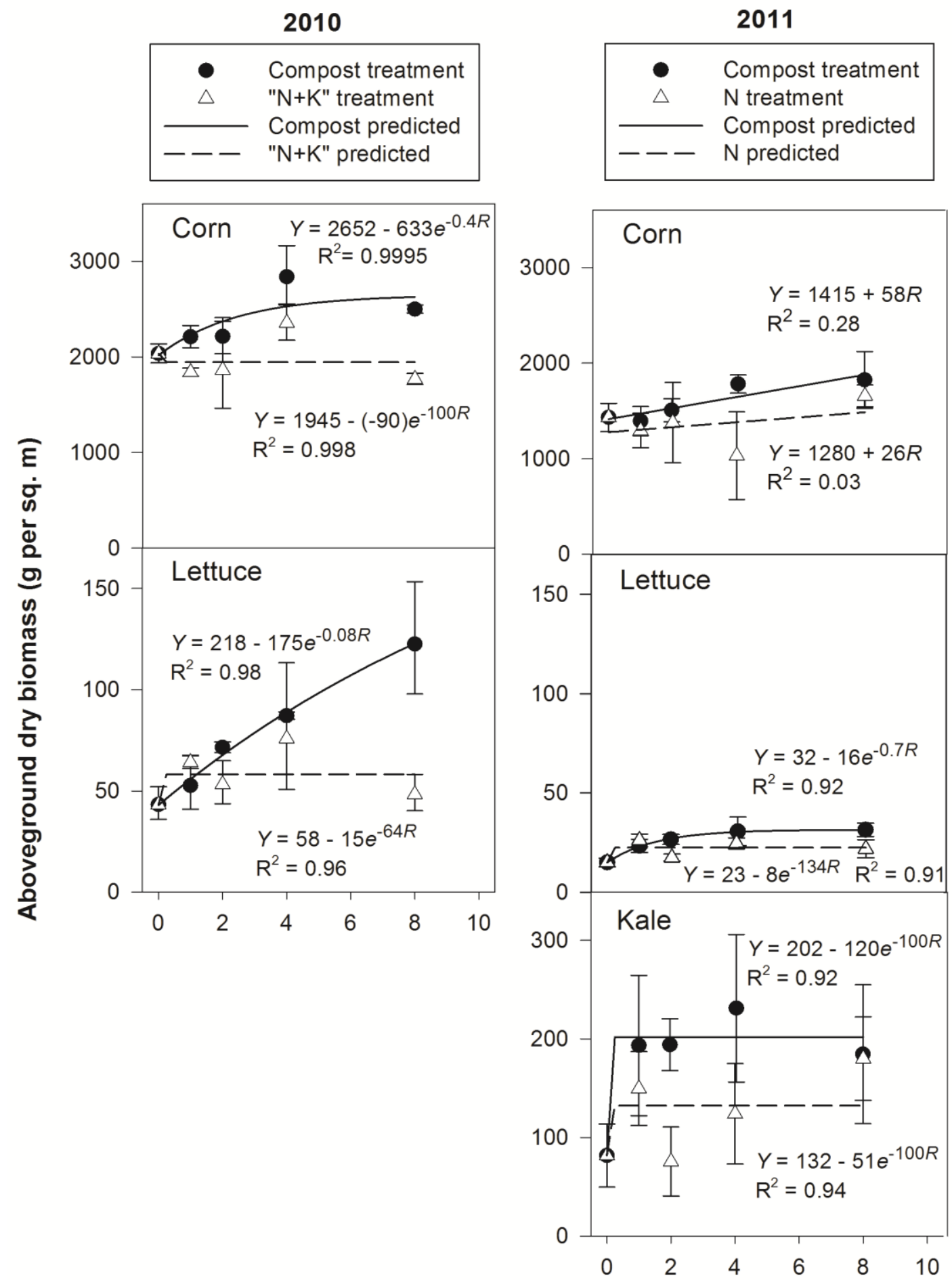

Fertility treatment rate

Figure 2.6: Crop growth across increasing amendment with composted poultry manure or blood meal $(\mathrm{N})$. Linear growth responses were modeled by ANOVA. Non-linear growth responses were modeled with an alternative to the Mitscherlich equation. Bars represent standard error of the mean. 
None of the crops responded to blood meal (Figure 2.6). Although growth of most crops increased with compost, the magnitude of that response differed considerably among species. In 2010, corn growth was significantly greater in the compost treatment than in the " $\mathrm{N}+\mathrm{K}$ " treatment (Figure 2.6, Table 2.6). However, compared to the response of the several weed species to compost, the effect on corn biomass was small. Even though the $8 \mathrm{X}$ rate of compost applied nutrients well above the rate recommended for corn production (Table 2.1, Cornell Cooperative Extension 2011 a), corn dry weight only increased by $3 \%$ from no compost addition to the $8 X$ rate. In 2011, corn growth did not increase significantly with compost amendment (Figure 2.6, Table 2.5). Over both years, corn growth response to fertility amendment was small, presumably because sufficient nutrients were supplied by the soil and the sod (and alfalfa hay in 2010) plowed down at the beginning of the experiments. In both years, lettuce biomass increased significantly with compost amendment, but not with blood meal (Figure 2.6, Table 2.6). This result supports grower recommendations for high fertility amendment rates for lettuce production (Cornell Cooperative Extension 2011b). However, due to the strong weed response to compost, good weed control would be crucial to maintain this yield benefit. When kale was grown in 2011, its growth did not differ significantly between treatments (Figure 2.6, Table 2.6). Variability in the data, possibly due to flea beetle herbivory, makes drawing strong conclusions about this species difficult, but kale appears to be less responsive to compost amendment than lettuce.

The lack of common lambsquarters, Powell amaranth, and giant foxtail growth response to blood meal amendment in this study differs from the strong growth 
response to conventional sources of $\mathrm{N}$ observed in many other studies of these or related weeds (Blackshaw et al. 2003; Blackshaw and Brandt 2008; Hoveland et al. 1976; Andreasen et al. 2006). This lack of response to N supplied as blood meal suggests sufficient $\mathrm{N}$ was supplied by mineralization of organic matter from the sod plowed down at the beginning of the experiment. Under the conditions of these trials, some other nutrient limited weed growth in the blood meal treatments but was supplied by the compost treatments, where strong growth responses were observed.

In contrast, velvetleaf growth responded similarly to compost and blood meal, suggesting that its response to compost was driven by $\mathrm{N}$. This difference is suggestive, because velvetleaf is an arbuscular mycorrhizal fungi (AMF) host species which has been shown to obtain P through its fungal associates (Stanley et al. 1993), whereas the other weeds in this study are either weakly- or non-mycorrhizal species. Giant foxtail is a weak AMF host (Vatovec et al. 2005). Common lambsquarters is a non-host species (Bassett and Crompton 1978; Vatovec et al. 2005). Although some relatives of Powell amaranth have been successfully inoculated with AMF (Arriola et al. 1997), in general the Amaranthaceae is believed to be a non-mycorrhizal family (Jordan et al. 2000; Vatovec et al. 2005). Thus one explanation for the differences in weed response to blood meal is that velvetleaf, due to its likely mycorrhizal associations, might have been less limited by immobile nutrients, such as $\mathrm{P}$, and better able to take advantage of the $\mathrm{N}$ supplied by the blood meal. In contrast, the other weeds' lack of response to the $\mathrm{N}$ supplied by blood meal could be explained by their growth being limited by a different nutrient which was supplied in the compost. Relatively few studies have tested weed response to $\mathrm{P}$, but common lambsquarters and redroot pigweed (a relative 
of Powell amaranth) have been shown to respond strongly to $\mathrm{P}$ amendment as conventional fertilizers (Santos et al. 2004; Hoveland et al. 1976; Vengris et al. 1955).

Regardless of which nutrient drove weed response to compost amendment, these results support fertility management based on soil testing and anticipated crop needs. Over-fertilization will, by definition, not benefit crop yield, but can increase weed growth. The practice of applying compost or manure at rates to supply the crop's N needs will often over-supply other nutrients, especially P (Eghball and Power 1999) and as such compost application can enhance weed growth. This is primarily an issue for livestock farms that produce some of their own feed and for organic vegetable farms, both of which rely on compost and manure for much of their $\mathrm{N}$ supply. A second major driver of overfertilization with compost and manure is the historical trend of separating livestock production and feed production (Hart et al. 1997). When some or all livestock feed is imported from off-farm, nutrients are added to the farm system. Returning those nutrients to the soil where the feed was grown is often impractical because manure and compost are heavy per unit nutrient in comparison to concentrated fertilizers and thus costly to transport. In some cases manure disposal has resulted in chronic over-fertilization of fields near barns (Hart et al. 1997).

Several approaches exist to address the problems described above. Reintegrating crop and livestock production has been proposed as a way to improve multiple aspects of agricultural sustainability, including nutrient cycling and management (Brummer 1998; Russelle et al. 2007; Schipanski and Bennett 2012). Other methods for reducing over-fertilization on livestock farms include composting manure to concentrate the nutrients and enable transporting the compost to fields 
further from the center of livestock production (DeLuca and DeLuca 1997), decreasing $\mathrm{P}$ supplements in animal feed, and reducing applications of $\mathrm{P}$ fertilizers used in addition to manure (Swink et al. 2009). In feed or vegetable production, if compost or manure amendment rates are calculated to re-supply the crop's predicted $\mathrm{P}$ removal, additional $\mathrm{N}$ can be supplemented from other sources (Eghball and Power 1999). Integrating green manures into the crop rotation may be a good strategy for supplying that additional $\mathrm{N}$.

Due to negative impacts of nutrient leaching and runoff on water quality (Camargo and Alonso 2006; Jongbloed and Lenis 1998), federal law now requires concentrated animal feeding operations (CAFOs) to develop and follow comprehensive nutrient management plans to limit soil N and P levels (USEPA 2003). The results of this study provide further motivation to reduce over-fertilization on any farm that uses organic nutrient amendments: corn is a nutrient demanding crop, but in both the 2010 and 2011 experiments, growth of several common weeds was increased by compost rates above those that maximized corn biomass production. 


\section{WORKS CITED}

Andreasen C, Litz A-S, and Streibig JC (2006) Growth response of six weed species and spring barley (Hordeum vulgare) to increasing levels of nitrogen and phosphorus. Weed Res 46:503-512

AOAC (1995) Official Methods of Analysis of AOAC International. Chapter 3 Fertilizers; Cunniff, P, ed.; Official Analytical Chemists International: Arlington, VA

Arriola L, Niemira, BA, and Safir, GR (1997) Border cells and arbuscular mycorrhizae in four Amaranthaceae species. Phytopathology 87:1240-1242

Bassett IJ and Crompton CW (1978) The biology of Canadian weeds. 32. Chenopodium album L. Can J Plant Sci 58:1061-1072

Blackshaw RE and Brandt RN (2008) Nitrogen fertilizer rate effects on weed competitiveness is species dependent. Weed Sci 56:743-747

Blackshaw RE, Brandt RN, Janzen HH, Entz T, Grant CA, and Derksen DA (2003) Differential response of weed species to added nitrogen. Weed Sci 51:532-539

Blackshaw RE, Brandt RN, Janzen HH, and Entz T (2004) Weed species response to phosphorus fertilization. Weed Sci 52:406-412

Brummer EC (1998) Diversity, stability, and sustainable American agriculture. Agron J 90:1-2

Buhler DD and Hoffman ML (1999) Anderson's guide to practical methods of propagating weeds and other plants. Lawrence, KS: Allen Press 248 p.

Camargo JA and Alonso Á (2006) Ecological and toxicological effects of inorganic nitrogen pollution in aquatic ecosystems: a global assessment. Environ Int 32:831-491 
Conklin AE, Erich MS, Liebman M, Lambert D, Gallandt ER, and Halteman WA (2002) Effects of red clover (Trifolium pratense) green manure and compost soil amendments on wild mustard (Brassica kaber) growth and incidence of disease. Plant Soil 238:245-256

Cornell Cooperative Extension (2011a) Cornell Guide for Integrated Field Crop Management. http://ipmguidelines.org/Fieldcrops/default.asp Accessed April 14,2011

Cornell Cooperative Extension (2011b) Integrated Crop and Pest Management Guidelines for Commercial Vegetable Production http://www.nysaes.cals.cornell.edu/recommends/18frameset.html Accessed April 14, 2011

Davis AS and Liebman M (2003) Cropping system effects on giant foxtail (Setaria faberi) demography: I. Green manure and tillage timing. Weed Sci 51:919-929

de Cauwer B, D'Hose T, Cougnon M, Leroy B, Bulcke R, and Reheul D (2011) Impact of the quality of organic amendments on size and composition of the weed seed bank. Weed Res 51:250-260

DeLuca TH and DeLuca DK (1997) Composting for feedlot manure management and soil quality. J Prod Agric 10:235-241

Di Tomaso JM (1995) Approaches for improving crop competitiveness through the manipulation of fertilization strategies. Weed Sci 43:491-497

Dyck E, Liebman M, and Erich MS (1995) Crop-weed interference as influenced by a leguminous or synthetic fertilizer nitrogen source: I. Double cropping experiments with crimson clover, sweet corn, and lambsquarters. Agric Ecosyst Environ 56:93-108

Eghball B, and Power JF (1999) Phosphorus- and nitrogen-based manure and compost applications: corn production and soil phosphorus. Soil Sci Soc Am J 63:895901 
Gardner FP, Pearce RB, and Mitchell RL (1985) Physiology of Crop Plants. Ames, IA: University of Iowa Press. 327 p.

Gomez KA and Gomez AA (1984) Statistical Procedures for Agricultural Research, $2^{\text {nd }}$ ed. New York: John Wiley. $680 \mathrm{p}$.

Greenwood DJ, Cleaver TJ, Turner MK, Hunt J, Niendorf KB, Loquens SMH (1980) Comparison of the effects of potassium fertilizer on the yield, potassium content and quality of 22 different vegetable and agricultural crops. J Ag Sci 95:441-56

Hart JM, Marx ES, Christensen NW, and Moore JA (1997) Nutrient management strategies. J Dairy Sci 80:2659-2666

Hartz TK and Johnstone PR (2006) Nitrogen availability from high-nitrogencontaining organic fertilizers. HortTechnol 16:39-42

Hoveland CS, Buchanan GA, and Harris MC (1976) Response of weeds to soil phosphorus and potassium. Weed Sci 24:194-201

Jongbloed AW and Lenis NP (1998) Environmental concerns about animal manure. J Anim Sci 76:2641-2648

Jordan NR, Zhang J, and Huerd S (2000) Arbuscular-mycorrhizal fungi: potential roles in weed management. Weed Res 40:397-410

Keeney DR. and Nelson DW (1982) Nitrogen-inorganic forms. Pages 643-698 in Page AL, Miller RH, and Keeney DR, eds. Methods of soil analysis. Part 2 Chemical and microbiological properties. 2nd ed. ASA, CSSA, SSSA, Madison, WI

Klapwyk JH and Ketterings QM (2005) Reducing analysis variability of the Illinois Soil Nitrogen Test with enclosed griddles. Soil Sci Soc Am J 69:1129-1134 
Liebman M, Menalled FD, Buhler DD, Richard TL, Sundberg DN, Cambardella CA, and Kohler KA (2004) Impacts of composted swine manure on weed and corn nutrient uptake, growth, and seed production. Weed Sci 52:365-375

Malhi SS and Nyborg M (1979) Rate of hydrolysis of urea as influenced by thiourea and pellet size Plant Soil 51:177-186

Mohler CL, Dykeman C, Nelson EB, and DiTommaso A (2012) Reduction in weed seedling emergence by pathogens following the incorporation of green crop residue. Weed Res 52:467-477

Mohler CL and Galford AE (1997) Weed seedling emergence and seed survival: separating the effects of seed position and soil modification by tillage. Weed Res 37:147-155

Morgan MF (1941) Chemical soil diagnosis by the universal soil testing system. Bull 450. Conn. Agric. Exp. Stn., New Haven, CT.

Murphy J and Riley JP (1962) A modified single solution method for the determination of phosphate in natural waters. Anal Chim Acta 27:31-36

Petersen SO, Stamatiadis S, and Christofides C (2004) Short-term oxide emissions from pasture soil as influenced by urea level and soil nitrate. Plant Soil 267:117-127

Russelle MP, Entz MH, and Franzluebbers AJ (2007) Reconsidering integrated croplivestock systems in North America. Agron J 99:325-334

Santos BM, Dusky JA, Stall WM, and Gilreath JP (2004) Influence of common lambsquarters (Chenopodium album) densities and phosphorus fertilization on lettuce. Crop Prot 23:173-176

Schipanski ME and Bennett EM (2012) The influence of agricultural trade and livestock production on the global phosphorus cycle. Ecosystems 15:256-268 
Stanley MR, Koide RT, and Shumway DL (1993) Mycorrhizal symbiosis increases growth, reproduction and recruitment of Abutilon theophrasti Medic. in the field. Oecologia 94:30-35

Swink SN, Ketterings QM, Chase LE, and Czymmek KJ, and Mekken JC (2009) Past and future phosphorus balances for agricultural cropland in New York State. J Soil Water Conserv 64:120-133

US Environmental Protection Agency (2003) Concentrated animal feeding operations (CAFO): Final Rule (68FR7176). Available at http://www.gpo.gov/fdsys/granule/FR-2003-02-12/03-3074/content-detail.html Accessed March 30, 2013. USEPA, Washington, DC.

Vatovec C, Jordan N, Huerd S (2005) Responsiveness of certain agronomic weed species to arbuscular mycorrhizal fungi. Renew Agr Food Syst 20:181-189

Vengris K, Colby WG, and Drake M (1955) Plant nutrient competition between weeds and corn. Agron J 47:213-216

Warren GP, Robinson JS, and Someus E (2009) Dissolution of phosphorus from animal bone char in 12 soils. Nutr Cycl Agroecosyst 84:167-78

Wolf A and Beegle D (1995) Recommended soil test for macronutrients: Phosphorus, potassium, calcium and magnesium. p. 30-38. In Recommended soil testing procedures for the northeastern United States. Northeastern Regional Publ. 493. 2nd ed. Univ. of Delaware, Newark 